\title{
Environmental Impact Assessment Of A Proposed Cement Plant In Southwestern Nigeria
}

\author{
${ }^{1}$ Ilalokhoin, P.O., ${ }^{2}$ Otaru, A.J., ${ }^{3}$ Odigure, J.O., ${ }^{4}$ Abdulkareem, A.S., and \\ ${ }^{5}$ Okafor, J.O. \\ ${ }^{I}$ (Academic Planing Unit, Federal University of Technology, Minna, Nigeria). \\ 2,3,4\&5 (Department of Chemical Engineering, Federal Univeristy of Technology, PMB 065, Gidan Kwanu, \\ Minna, Niger State, Nigeria).
}

\begin{abstract}
The research article is focused on the Environmental Impact Assessment of a proposed cement plant to be located in Sagamu, Ogun State, Southwestern Nigeria. Environmental impact assessment studies are carried out to obtain environmental clearance for establishment of a production plant in accordance with the Federal Environmental Protection Agency rules and guidelines for predicting the ground level concentration of pollutants. A dispersion modelling technique was used to develop a model equation. Data generated from field and experimental measurements were fitted into the developed model and thereafter the model was simulated to determine the spread of particulate matter and carbon dioxide concentrations from the proposed plant. The results obtained were compared with the Nigerian Ambient Air Quality Standards and World Health Organization maximum limits for an 8-hourly average time and found to be within the permissible limits.
\end{abstract}

Keywords: Cement plant, Environment, Modelling, Nigeria and Pollutants.

\section{Introduction}

An environmental impact assessment (EIA) is an assessment of the possible impact (positive or negative) that a proposed project may have on the environment; considering natural, social and economic aspects (International Association for Impact Assessment, 1999). The purpose of such an assessment is to ensure that decision makers put all these factors into consideration to enable them determine the desirability or otherwise of the proposed project. The International Association for Impact Assessment (IAIA) defines an environmental impact assessment as "the process of identifying, predicting, evaluating and mitigating the biophysical, social, and other relevant effects of development proposals prior to major decisions being taken and commitments made (International Association for Impact Assessment, 1999).

Environmental Impact Assessment (EIA) is a relatively new planning and decision making tool first enshrined in the United States in the National Environmental Policy Act of 1969 (U.S. EPA, 2004). It is a formal study process used to predict the environmental consequences of any developmental project. EIA thus ensures that the potential problems are foreseen and addressed at an early stage in project planning and design (Carroll and Turpin, 2009). Environmental Assessment is taken up as a rapid assessment technique for determining the current status of the environment and identifying impact of critical activities on environmental parameters. Based on this analysis, an Environmental Management Plan that would ensure impact monitoring and mitigation planning can be drawn for proper planning of the new plant.

In view of the fact that development is an ever growing process, its impact on the environment is also ever increasing, leading to rapid deterioration of environmental conditions. As a result Environmental Impact Assessment provides a rational approach to sustainable development. Extensively developed rapid assessment techniques often avoid carrying out of detailed studies which need more resources in terms of time and money (CSI, 2002).

The EIA statement covers brief description of project, brief description of existing environment, likely impact of project, the mitigation and protection measures, consideration of alternatives, and summary with conclusions (FEPA 1990). The impact assessment of a proposed cement factory is of immense important for the purpose of providing futuristic informations about the likely environmental impacts that may result during the activities of the proposed company.

Portland cement manufacture can cause environmental impacts at all stages of the process. These include emissions of airborne pollution in the form of dust, gases, noise and vibration when operating machinery and during blasting in quarries, consumption of large quantities of fuel during manufacture, release of $\mathrm{CO}_{2}$ from the raw materials during manufacture, and damage to the environment from quarrying. The use of equipment to reduce dust emissions during quarrying and manufacture of cement, and equipment to trap and separate exhaust gases are coming into increased use. Environmental protection also includes the re-integration of quarries into 
the countryside after they have been closed down by returning them to nature or re-cultivating them (Marlowe et al.. 2002).

An independent research effort was conducted to identify critical issues for the cement industry and it was found that the most important environmental, health and safety performance issues facing the cement industry are atmospheric releases including greenhouse gas emissions, dioxin, $\mathrm{NO}_{x}, \mathrm{SO}_{2}$, and particulates, accidents and worker exposure to dust (Hendriks et al., 2004).

The $\mathrm{CO}_{2}$ associated with Portland cement manufacture falls into 3 categories: $\mathrm{CO}_{2}$ derived from decarbonization of limestone, $\mathrm{CO}_{2}$ from kiln fuel combustion and $\mathrm{CO}_{2}$ produced by vehicles in cement plants and distribution. The first source is fairly constant: within the ranges of $0.47-0.54 \mathrm{Kg} \mathrm{CO}_{2}$ per $\mathrm{Kg}$ of cement, typically values around $0.50 \mathrm{Kg}$ world-wide. Second source varies with plant efficiency. For instance efficient precalciner plant will produce $0.24 \mathrm{Kg} \mathrm{CO}$ per $\mathrm{Kg}$ cement, while low-efficiency wet process as high as $0.65 \mathrm{Kg}$ of $\mathrm{CO}_{2}$ per $\mathrm{Kg}$ of cement (Environmental Health and Safety Performance Improvement, 2002). It has been reported that in typical modern practices (for example U.K.) averaging around $0.30 \mathrm{Kg}$ of $\mathrm{CO}_{2}$ per $\mathrm{Kg}$ of cement produced. Third source is almost insignificant at $0.002-0.005$. So the typical $\mathrm{CO}_{2}$ is around $0.80 \mathrm{Kg} \mathrm{CO}_{2}$ per $\mathrm{Kg}$ finished cement. This leaves aside the $\mathrm{CO}_{2}$ associated with electric power consumption, since this varies according to the local generation type and efficiency. Typical electrical energy consumption is of the order of 90 $-150 \mathrm{KWh}$ per ton of cement, equivalent to $0.09-0.15 \mathrm{Kg} \mathrm{CO}_{2}$ per $\mathrm{Kg}$ of finished cement if the electricity is coal generated (Marlowe et al 2002).

Overall, with nuclear or hydroelectric power and efficient manufacturing, $\mathrm{CO}_{2}$ generation can be as little as $0.07 \mathrm{~kg}$ per $\mathrm{kg}$ cement, but can be as high as twice this amount for low efficient nuclear or hydroelectric plant. The thrust of innovation for the future is to reduce source 1 and 2 by modification of the chemistry of cement, by the use of wastes, and by adopting more efficient processes. Although cement manufacturing is clearly a very large $\mathrm{CO}_{2}$ emitter, concrete (of which cement makes up to about $15 \%$ ) compares quite favourbly with other building systems in this regard (Marlowe et al 2002).

This present study is motivated by the fact that Portland cement is the most widely used building material in the world with about 1.56 billion tonnes (1.72 billion tons) produced each year. Annual global production of Portland cement concrete hovers around 3.8 million cubic meters ( 5 billion cubic yards) per year (Cement Association of Canada, 2001). In the U.S., rigid pavements are the largest single use of Portland cement and Portland cement concrete (ACPA, 2002). It is therefore important to conduct an Environmental Impact Assessment of a proposed cement factory considering the negative impacts of cement companies on the environment. This study will also develop a predictive model for pollutants' dispersion at various distances from the point of discharge. This will serve as a means of controlling the activities of the proposed cement factory in terms of environmental pollution.

\section{Research Methodology}

World population and rapid increase in urbanization especially in developing countries like Nigeria where efforts are concentrated in the development of cities through provision of facilities such as roads, houses, etc, results in huge demand for cement. However, the quantity of cement produced in the country is far less than is required hence the need for a large percentage of imports to meet the local demand, the consequence of which is the high price of cement. The situation has forced the Nigerian government and private organizations to invest in cement production for the purpose of replacing the imported cement with locally produced cement. The idea was motivated by the availability of basic materials for the production of cement in the country. Efforts in this direction have led to the proposed location of Cement Company with Capacity of producing 1 million tonnes per year in Shagamu, Ogun State. Considering the impact of the cement company on the environment, there is the need to conduct an EIA of the proposed cement company before operation begins, which is the purpose of this study.

All the experimental works carried out in this study are aimed at analyzing and determining the concentrations of pollutants in the proposed site. Though all the experimental reports were conducted by a team of environmental analysts, the data were collected for the purpose of reporting the environmental impacts and to enhance the better understanding of the model technique.

\section{EIA Activities}

In course of executing the EIA, a preliminary assessment involving literature review, desk studies as well as consultations were carried out. A multidisciplinary field sampling was conducted to obtain baseline information. Laboratory analyses were also conducted. These together formed the basis for the EIA report.

\section{Sample collection and handling}

This was carried out in accordance with FEPA Guidelines. Where logistics and safety considerations precluded strict compliance with the above guidelines and standards, other proven, scientifically acceptable 
methods of sample collection where used. Sampling was conducted at specific distances: $500 \mathrm{~m}, 1000 \mathrm{~m}$ and $5000 \mathrm{~m}$ from the monitored stations.

\section{Laboratory analysis}

The methods of analysis used are those specified in International Analytical Standard such as APHA for water quality. Trace metals analyses were done using Atomic Absorption Spectrophotometer duly calibrated using standards. The following analysis where performed on the collected samples.

\section{Dissolved oxygen and temperature measurement}

The equipment has the following characteristics and functions.

(a) it is a portable, weatherproof dissolved oxygen measuring instrument complete with cable, sensor, comprehensive operation manuals, and with the use of a DC power source. (e.g. YSI model 59 meter, YSI 5739 probe, YSI 5795A submersible stirrer with reel and cable or an approved similar instrument). Which is capable of measuring:-

- a dissolved oxygen level in the range of $0-20 \mathrm{mg} / \mathrm{l}$ and $0-200 \%$ saturation; and

- a temperature of 0-45 degree Celsius.

(b) It has a membrane electrode with automatic temperature compensation complete with a cable.

\section{Turbidity measurement}

The instrument is a portable, weatherproof turbidity-measuring instrument called a nephelometer. The sample is illuminated by means of light and the light scattered by the particles is measured in a direction at right angles to that of the incident light. The intensity of the scattered light is proportional to the turbidity. The turbidity of the sample is compared with that of a standard turbidity suspension (Kreshkov, 1996).

\section{Water depth detector}

A portable, battery-operated echo sounder is used for the determination of water depth at each designated monitoring station. This is either a handheld device or affixed to the bottom of the work boat, if the same vessel is to be used throughout the monitoring programme (Kreshkov, 1996).

\section{Determination of $\mathbf{p H}$}

Before measuring the $\mathrm{pH}$ of the test sample, the electrode was thoroughly washed with distilled water and then with the sample. The temperature control was set to the temperature of the sample and the system was allowed to stabilize before the reading was finally taken. The determination was made in unstirred solution to avoid loss of carbon dioxide or other volatile component, which would alter the pH value (Kreshkov, 1996).

\section{Determination of electrical conductivity}

The sample temperature was brought close to $20^{\circ} \mathrm{C}$, the conductivity cell was thoroughly rinsed with some of the sample. The tube is then filled to the brim, ensuring no air bubble adheres to electrode. Two tubes containing the sample were placed in a water bath maintained at $20^{\circ} \mathrm{C}$ and allowed for 30 minutes to reach thermal equilibrium. The cell was thoroughly resisted with the first tube and measurement was made in the second tube accordingly.

\section{Determination of carbonate, bicarbonate and carbon dioxide}

The concentrations of the three carbonate species i.e. carbonate, bicarbonate and carbon dioxide are interrelated by chemical equilibra involving $\mathrm{pH}$. The concentration of the carbonate, bicarbonate and carbon dioxides are calculated from $\mathrm{pH}$, total alkalinity, temperature and ionic strength.

Exact Mathematical Solution - The total alkalinity and carbonate alkalinity or phenol phetalein alkalinity expressed in $\mathrm{mg} / \mathrm{l}$ as in $\mathrm{CaCO}_{3}$ is given by the following equation. The concentrations of the various ions are expressed in $\mathrm{mol} / \mathrm{l}$.

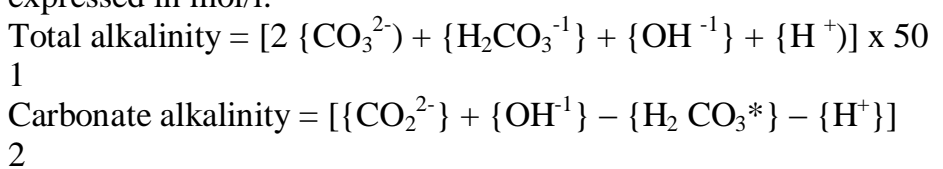

where $\left[\mathrm{H}_{2} \mathrm{CO}_{3}{ }^{*}\right]$ is the free carbonic acid, this is the sum of carbonic acid and aqueous carbon dioxide.

The total inorganic carbon $\mathrm{C}_{\mathrm{t}}$ expressed in $\mathrm{mol} / \mathrm{l}$ is given by the difference between the values of the two alkalinities

3

$$
\mathrm{C}_{\mathrm{t}}=\left[\mathrm{CO}_{3}{ }^{2-1}\right]+\left[\mathrm{H}_{2} \mathrm{CO}_{3}^{-1}\right]+\left[\mathrm{H}_{2} \mathrm{CO}_{3}\right]
$$

4

$$
\mathrm{C}_{\mathrm{t}}=[\{\text { total alkalinity }\}-\{\text { carbonic alkalinity }\}] / 50
$$


At sample $\mathrm{pH}$ values below a value of 8.3 , the carbonate alkalinity is negative and its value must be determined by titration of acidity (Kreshkov, 1996).

The concentration of carbonate, bicarbonate and free $\mathrm{CO}_{2}$ are given by the following expression.

5

$$
\left.\left[\mathrm{CO}_{3}{ }^{2-}\right]=\mathrm{C}_{\mathrm{t}} /\left(\mathrm{a}_{\mathrm{H}}\right\}^{2} \mathrm{f}_{1} \mathrm{f}_{2} / \mathrm{K}_{1} \mathrm{~K}_{2}+\left\{\mathrm{a}_{\mathrm{H}} \mathrm{f}_{2}+1\right\} / \mathrm{K}_{2}\right)
$$

6

$$
\left[\mathrm{H}_{2} \mathrm{CO}_{3}^{*}\right]=\left(\mathrm{C}_{\mathrm{t}} /\left\{\mathrm{K}_{1} / \mathrm{a}_{\mathrm{H}} \mathrm{f}_{1}\right\}+\left\{\mathrm{K}_{1} \mathrm{~K}_{2} / \mathrm{a}_{\mathrm{H}}^{2} \mathrm{f}_{1} \mathrm{f}_{2}\right\}\right)
$$

$$
\left[\mathrm{H}_{2} \mathrm{CO}_{3}^{-1}\right]=\left(\mathrm{C}_{\mathrm{t}} /\left\{\mathrm{a}_{\mathrm{H}} \mathrm{f}_{1} / \mathrm{K}_{1}\right\}+1+\left\{\mathrm{K}_{2} / \mathrm{a}_{\mathrm{H}} \mathrm{f}_{2}\right\}\right)
$$

7

where $\mathrm{k}_{1}$ and $\mathrm{k}_{2}$ are respectively the first and second acid dissociation constant of carbonic acid and temperature dependent. $f_{1}$ and $f_{2}$ are respective activity coefficient, which are dependent on ionic strength of the solution. The electrical conductivity of the solution varies with the ionic strength and $\mathrm{a}_{\mathrm{h}}$ is $\mathrm{pH}$ (Kreshkov, 1996).

\section{Laboratory measurement/analysis of suspended solids}

Analysis of suspended solids, ammonia, and zinc concentration, were carried out in an international accredited laboratory. Water samples of about $1000 \mathrm{ml}$ were collected at the monitoring stations for carrying out the laboratory suspended solids (SS) determination. The detection limit is set at $1 \mathrm{mg} / \mathrm{l}$ or better. The Suspended Solids determination work is carried out within 24 hours after collection of the water samples.

\section{Suspended solids}

Sampling is carried out using a water sampler which comprises a transparent PVC cylinder, with a capacity of not less than 2 litres, and can be effectively sealed with latex cups at both ends. The sampler has a positive latching system to keep it open and prevent premature closure until released by a messenger when the sampler is at the selected water depth

Water samples for suspended solids measurement are collected in high density polythene bottles, packed in ice (cooled to $4^{\circ} \mathrm{C}$ without being frozen), and delivered to the laboratory as soon as possible after collection.

A crucible is heated to about 500 to $600{ }^{\circ} \mathrm{C}$ for about $30 \mathrm{~min}$, cooled in a decicator and then weighed. The process is repeated until a constant weight is obtained. Then the V.c.c. of the unfiltered water sample is taken in a crucible and evaporated on a water bath. The solid residue is heated, and cooled in a decicator and then weighed. This process is repeated until a constant weight is obtained (Kreshkov, 1996).

Total suspended solid $=$ total solids - total dissolved solids

The difference in the two weights gives the weight of solids $(\mathrm{Wg})$ obtained from evaporation of $\mathrm{V} \mathrm{ml}$ of sample. $\mathrm{V} \mathrm{ml}$ of sample contains $\mathrm{W}^{*} 1000 \mathrm{mg}$

$1000 \mathrm{ml}=(\mathrm{W} * 1000 * 1000) / \mathrm{V}$

8

Where $\mathrm{V}=$ volume of sample $(\mathrm{ml})$

$\mathrm{W}=$ weight of solids $(\mathrm{g})$

\section{Particulate Matter}

Equipment for sampling particulate matter is the SKC Deployable Particulate Sampler. The pump flow rate is calibrated to $10 \mathrm{~L} / \mathrm{min}$ and the pre-sample flow rate is recorded. Mount bracket at desired sampling location and install sampling head on mounting bracket. The rain cover is installed on the sampling head, and the pump is turned and pertinent data recorded. After the desired sampling period, record sample and stop time. The rain cover is removed and calibration train reinstated to verify pump flow rate. The post-sample flow rate recorded and the pump turned off. The pertinent information is recorded and the sampling head is removed and moved to a clean place before being taken to the laboratory for analysis (Smidth, 2006).

\section{Water Studies}

Measurements was taken at 3 water depths, namely, $1 \mathrm{~m}$ below water surface, mid-depth and $1 \mathrm{~m}$ above stream or sea bed, except where the water depth less than $6 \mathrm{~m}$, the mid-depth station may be omitted. Where the water depth is less than $3 \mathrm{~m}$, only the mid-depth station will be monitored.

Duplicates in-situ measurements and samples collected from each independent sampling event are required for all parameters to ensure a robust statistically interpretable dataset.

Aluminium - using an Atomic Absorption Spectrophotometer duly calibrated using standards. $1 \mathrm{ml} 0.02 \mathrm{M}$ $\mathrm{H}_{2} \mathrm{SO}_{4}$ was added to each standard and mixed. Then $1 \mathrm{ml}$ ascorbic acid solution was added and mixed. Add 10 $\mathrm{ml}$ buffer solution and mix. With a volumetric pipette add $5.00 \mathrm{ml}$ working dye reagent and mix. It is immediately made up to $50 \mathrm{ml}$ with distilled water, mixed and allowed to stand for 5 to 10 minutes. 
The absorbance is read at $535 \mathrm{~nm}$ within $15 \mathrm{~min}$ of addition of dye, adjusting instrument to zero absorbance with the standard containing no aluminum. A calibration curve is plotted between absorbance and Aluminum concentration.

Calculation - Read aluminum concentration in the sample against its absorbance value from the calibration curve (Kreshkov, 1996).

Calcium - A $50 \mathrm{ml}$ sample or an aliquot is diluted to $50 \mathrm{ml}$ such that the calcium content is not more than 10 mg. Samples which contain alkalinity greater than $300 \mathrm{mg} / \mathrm{l}$ are neutralized with acid, boiled for 1 min and cooled before titration. Adding $2 \mathrm{ml} \mathrm{NaOH}$ solution or a volume sufficient to produce a $\mathrm{pH}$ of 12 to 13 , titration is started immediately after addition of the alkali. Add 0.1 to $0.2 \mathrm{~g}$ indicator mixture and titrate with EDTA solution, with continuous mixing, till the color changes from pink to purple. The end point is checked by adding 1 to 2 drops excess titrate to make certain that no further color change occurs (Kreshkov, 1996).

Calculation

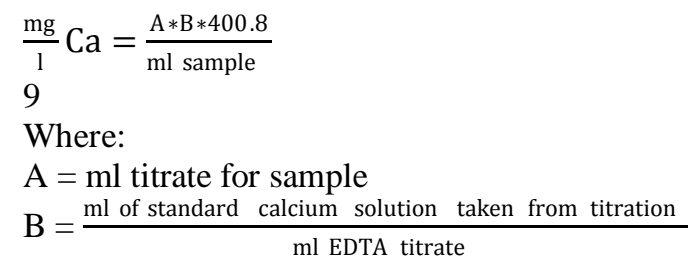

Chloride - Using a $100 \mathrm{ml}$ sample or a suitable portion diluted to $100 \mathrm{ml}$. If the sample is colored or turbid, add $3 \mathrm{ml} \mathrm{Al}(\mathrm{OH})_{3}$ suspension, mixing and allow to settle and filter. Adding $1 \mathrm{ml} \mathrm{K}_{2} \mathrm{CrO}_{4}$ indicator solution, it is titrate with $\mathrm{AgNO}_{3}$ titrate to a pinkish yellow end point. The titration it is repeated with distilled water blank (Kreshkov, 1996).

Calculation

$\frac{\mathrm{mg}}{\mathrm{l}} \mathrm{Cl}=\frac{(\mathrm{A}-\mathrm{B}) * 35450}{\mathrm{ml} \mathrm{sample}}$

10

where

$A=m l$ titration for sample

$\mathrm{B}=\mathrm{ml}$ titration for blank

$\mathrm{N}=$ molarity of $\mathrm{AgNO}_{3}$

Iron - For total iron: Take $50 \mathrm{ml}$ of mixed sample into a $125 \mathrm{ml}$ conical flask. If this volume is expected to contain more than $200 \mu \mathrm{g}$ iron use a smaller portion and dilute to $50 \mathrm{ml}$. Adding $2 \mathrm{ml}$ concentrated $\mathrm{HCl} 1 \mathrm{ml}$ $\mathrm{NH}_{2} \mathrm{OH}, \mathrm{HCl}$ solution, a few glass beads and heat to boiling till the volume is reduced to $15-20 \mathrm{ml}$, cool, and transfer to a $50 \mathrm{ml}$ volumetric flask. Adding $10 \mathrm{ml} \mathrm{NH}_{4} \mathrm{C}_{2} \mathrm{H}_{3} \mathrm{O}_{2}$ buffer solution and $4 \mathrm{ml}$ phenanthroline solution dilute to the mark with water. Mix and allow 10-15 min. for color development. Take photometer readings at $510 \mathrm{~nm}$.

Dissolved iron: Filter sample through a $0.45 \mu \mathrm{m}$ membrane filter into a vacuum flask containing $1 \mathrm{ml}$ concentrated $\mathrm{HCl} / 100 \mathrm{ml}$ sample. It is analysed as above and expressed as total dissolved iron.

Ferrous iron: Acidify freshly collected sample with $2 \mathrm{ml}$ conc. $\mathrm{HCl} / 100 \mathrm{ml}$ of sample, withdraw $50 \mathrm{ml}$ portion,

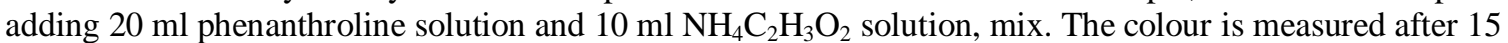
minutes.

Calculate ferric iron by subtracting ferrous from total iron.

Colour measurement: a series of standards is prepared by accurately pipetting volumes of standard iron solution into $125 \mathrm{ml}$ conical flask, and diluted to $50 \mathrm{ml}$. Plot a calibration curve.

Calculation - Read from the calibration curve and calculate the iron content (Kreshkov, 1996).

$\frac{\mathrm{mg}}{\mathrm{l}} \mathrm{Fe}=\frac{\mu \mathrm{g} \mathrm{Fe} \text { (in final volume ) }}{\mathrm{ml} \text { sample }}$

11

Manganese - Taking a suitable volume of sample, containing 0.05 to $2.0 \mathrm{mg} \mathrm{Mn}$, in a $250 \mathrm{ml}$ conical flask, add $5 \mathrm{ml}$ special reagent and one drop $\mathrm{H}_{2} \mathrm{O}_{2}$. Concentrated to $90 \mathrm{ml}$ by boiling or diluted to $90 \mathrm{ml}$, then add $1 \mathrm{~g}$ $\left(\mathrm{NH}_{4}\right)_{2} \mathrm{~S}_{2} \mathrm{O}_{8}$ and boil for $1 \mathrm{~min}$ then it is cooled under the tap. It is then diluted to $100 \mathrm{ml}$ with distilled water. Standards are prepared in the range of the sample concentration by treating various amounts of standard Mn solution in the same manner as above. Use light path of $1 \mathrm{~cm}$ for $\mathrm{Mn}$ range of $100-1500 \mu \mathrm{g} / 100 \mathrm{ml}$ final 
reaction volume. Plot standard calibration curve and read Mn concentration in the final $100 \mathrm{ml}$ reaction volume from the standard curve (Kreshkov, 1996).

$$
\begin{aligned}
& \text { Calculation } \\
& \frac{\mathrm{mg}}{\mathrm{l}} \mathrm{Mn}=\frac{\mu \mathrm{gMn} / 100 \mathrm{ml} \text { final volume }}{\mathrm{mlsample}}
\end{aligned}
$$

Nitrogen ammonia - Using a Spectrophotometer for use at $640 \mathrm{~nm}$ with a cell of $1 \mathrm{~cm}$ or longer light path, take a $25 \mathrm{ml}$ sample in a $50 \mathrm{ml}$ conical flask, and add with mixing, $1 \mathrm{ml}$ phenol solution, $1 \mathrm{ml}$ sodium nitroprusside solution, and $2.5 \mathrm{ml}$ oxidising solution. Avoid light exposure by suitably covering the flasks at room temperature. Absorbance is measured after $1 \mathrm{~h}$ at $640 \mathrm{~nm}$.

Calculation - Prepare calibration curve by plotting absorbance readings against ammonia concentration of standards, compute sample concentration from the standard curve (Kreshkov, 1996).

Phosphorus - To $50 \mathrm{ml}$ portion of thoroughly mixed sample was added one drop of phenolphthalein indicator solution. If a red colour develops, add $10 \mathrm{~N} \mathrm{H}_{2} \mathrm{SO}_{4}$ to just discharge colour. Then $1 \mathrm{ml} 10 \mathrm{~N} \mathrm{H}_{2} \mathrm{SO}_{4}$ is added and either $0.4 \mathrm{~g}\left(\mathrm{NH}_{4}\right)_{2} \mathrm{~S}_{2} \mathrm{O}_{8}$ or $0.5 \mathrm{~g} \mathrm{~K}_{2} \mathrm{~S}_{2} \mathrm{O}_{8}$. It is boiled gently on a preheated hot plate for 30 to $40 \mathrm{~min}$ or until a final volume of $10 \mathrm{ml}$ is reached. It is cooled and diluted to $30 \mathrm{ml}$ with distilled water, add one drop phenolphthalein indicator solution and neutralized to a faint pink colour with $\mathrm{NaOH}$ and made up to $100 \mathrm{ml}$ with distilled water. Do not filter if any precipitate is formed at this stage. It will redissolve under acid conditions of the colourometric test. Taking $50 \mathrm{ml}$ of the digested sample into a $125 \mathrm{ml}$ conical flask, add 1 drop of phenolphthalein indicator. Any red colour is discharged by adding $5 \mathrm{~N} \mathrm{H} 2 \mathrm{SO} 4.8 \mathrm{ml}$ of the combined reagent is added and mixed. Absorbance is measured for each sample at $880 \mathrm{~nm}$ after waiting for 10 minutes, but no more than 30 minutes. Use reagent blank as reference. Subtract blank absorbance from sample absorbance reading.

Preparation of calibration curve: Prepare calibration from a series of standards between 0.15-1.30 mgP/l range (for a $1 \mathrm{~cm}$ light path) by first carrying the standards through identical persulphate digestion process. Use distilled water blank with the combined reagent. Plot a graph with absorbance versus phosphate concentration to give a straight line. Test at least one phosphate standard with each set of samples (Kreshkov, 1996).

Calculation

total $\mathrm{P}$ as $\frac{\mathrm{mg}}{\mathrm{l}} \mathrm{P}=\frac{\mathrm{mg} \mathrm{P}_{\text {from the curve }} * 1000}{\mathrm{ml} \text { sample }}$

Potassium - Using a Flame photometer. A blank and potassium calibration standards are prepared, in any of the applicable ranges, $0-100,0-10$, or $0-1 \mathrm{mg} \mathrm{K} / \mathrm{l}$. Emissions are measured at $766.5 \mathrm{~nm}$ and used to prepare a calibration curve. The potassium concentration of the sample or diluted sample is determined from the curve (Kreshkov, 1996).

Calculation

$\frac{\mathrm{mg}}{\mathrm{l}} \mathrm{K}=\frac{\mathrm{mg}}{\mathrm{l}} \mathrm{K}$ (from calibration curve) $*$ Dilution

14

Where

Dilution $=\frac{\mathrm{ml} \text { sample }-\mathrm{ml} \text { distilled } \text { water }}{\mathrm{ml} \text { sample }}$

Sodium - A blank and sodium calibration standards are prepared, in any of the applicable ranges, 0-100, 0-10, or $0-1 \mathrm{mg} \mathrm{Na} / \mathrm{l}$. The instrument is set to zero with standard containing no sodium. The emissions are measured at $589 \mathrm{~nm}$ and used to prepare a calibration curve. The sodium concentration of the sample or diluted sample is determined from the curve (Kreshkov, 1996).

$$
\frac{\mathrm{mg}}{\mathrm{l}} \mathrm{Na}=\frac{\mathrm{mg}}{\mathrm{l}} \mathrm{Na} \text { (from the calibration curve) } * \text { Dilution }
$$

Statistical Analysis - Errors in field data include those resulting from the instrument and those introduced by the observer. However other errors arise from the method of sampling. Errors often arise from two-stage sampling or that the samples collected are not a representative sampling of the medium. There are also spatial 
variations of the same medium e.g. soil and water. Thus it is necessary to determine the true mean and the estimated variance among the number of samples taken, so as to establish a reasonable level of confidence in the results obtained. A good result is obtained when the variance is within 5\% of the mean. All the analyses were conducted in triplicate and the results reported are the average values with average deviation of $\pm 2 \%$.

\section{Soils, Land Use And Agriculture}

Soil studies were undertaken to obtain information with regards to the physical and chemical properties, which are relevant to the determination of soil nutrient availability, and hence the soil fertility and productivity of the area in terms of plant growth.

\section{Working Model}

\section{The Gaussian Plume Model}

The Gaussian dispersion model was used to determine the predicted groundlevel concentrations of particulate matter at various distances downwind of the cement plant.

\section{Derivation of the gaussian plume model}

By performing a mass balance on a small control volume, a simplified diffusion equation which describes a continous cloud of material dispersing in a turbulent flow can be written as (Beychok, 2005)

$\frac{d C}{d t}+U \frac{d C}{d x}=\frac{d}{d y}\left(K_{y} \frac{d C}{d y}\right)+\frac{d}{d z}\left(K_{z} \frac{d C}{d z}\right)+S$

16

$\mathrm{x}=$ along-wind coordinate measured in wind direction from the source $(\mathrm{m})$

$\mathrm{y}=$ cross-wind coordinate direction $(\mathrm{m})$

$\mathrm{z}=$ vertical coordinate measured from the ground $(\mathrm{m})$

$C_{(x, y, z)}=$ mean concentration of diffusing substance at point $(\mathrm{x}, \mathrm{y}, \mathrm{z}),\left(\mathrm{g} / \mathrm{m}^{3}\right)$

$K_{y}, K_{z}=$ eddy diffusivity in the direction of the $y$ - and z-axes, $\left(\mathrm{m}^{2} / \mathrm{s}\right)$

$\mathrm{U}=$ mean wind velocity along the $\mathrm{X}$-axis $(\mathrm{m} / \mathrm{s})$

$\mathrm{S}=$ source/sink term $\left(\mathrm{g} / \mathrm{m}^{2} \mathrm{~s}\right)$

$\frac{d C}{d t}+U \frac{d C}{d x}$ gives the time rate of change and advection of the cloud by the mean wind

$\frac{d}{d y}\left(K_{y} \frac{d C}{d y}\right), \frac{d}{d z}\left(K_{z} \frac{d C}{d z}\right)$ gives the turbulent diffusion of material relative to the centre of the pollutant cloud

$\mathrm{S}=$ source term which represents the net production of pollutant due to the source $(\mathrm{g} / \mathrm{sec})$

Assumptions:

The following assumptions were made in developing the mathematical model for dust emission from cement plant.

1. A continuous and point source emission.

2. Diffusion in the downwind direction is negligible relative to their transport by the wind. In other words, only vertical and crosswind diffusion occurs.

3. Vertical and crosswind diffusion occur according to Gaussian distribution.

4. Constant wind speed from source point to receptor, i.e. horizontal wind velocity and the mean wind direction are constant.

5. Atmospheric turbulence is also constant

6. Throughout the plume travel distance, all of the plume is conserved, meaning no disposition or washout of the plume components.

7. Dispersion coefficient for rural terrain was used and assumption of an expanding conical plume implicity requires homogeneous turbulence throughout the $\mathrm{x}, \mathrm{y}$, and $\mathrm{z}$-dimensions of the plume (Beychok, 2005). 
The Figure 1 shows a visualization of a bouyant air pollutant dispersion plume in the atmosphere from a point emission source. (Beychok, 2005).

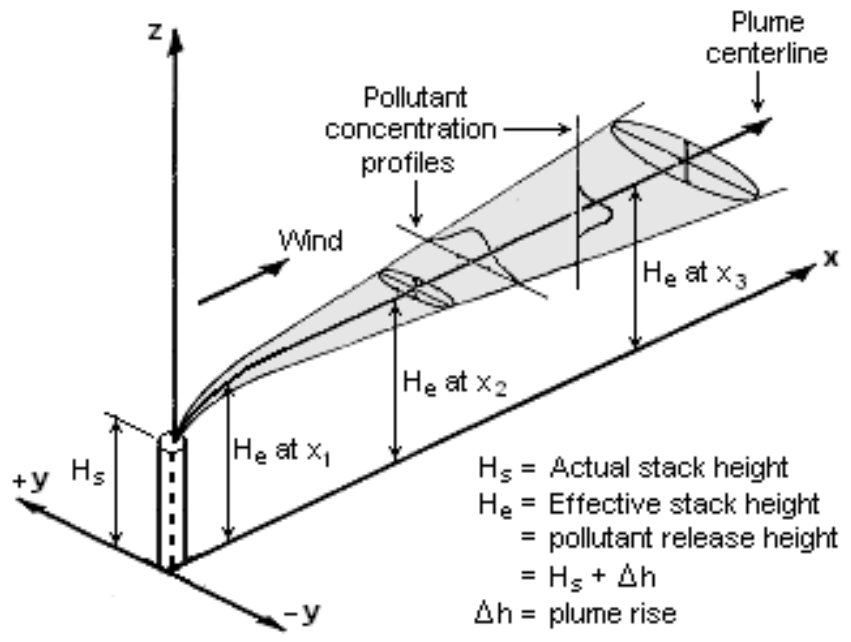

Figure 1: Visualisation of a bouyant Gaussian air dispersion plume in the atmosphere from a point emission source.

The simplified Gaussian equation is represented by equation 17

$C_{(x, y, z,)}=\frac{Q}{4 \pi x \sqrt{K_{y} K_{z}}} \exp \left(\frac{-y^{2}}{4 K_{y}\left({ }^{x} / U\right.}\right) \exp \left(\frac{-Z^{2}}{4 K_{z}(x / U)}\right)$

17

Where $\mathrm{Q}=$ source emission rate $(\mathrm{g} / \mathrm{sec})$

$\mathrm{U}=$ horizontal wind velocity $(\mathrm{m} / \mathrm{sec})$

$K_{y}, K_{z}=$ eddy diffusivity in the direction of the $y$ - and z-axes, $\left(\mathrm{m}^{2} / \mathrm{s}\right)$

$\mathrm{x}=$ along-wind coordinate measured in wind direction from the source $(\mathrm{m})$

$\mathrm{y}=$ cross-wind coordinate direction $(\mathrm{m})$

$\mathrm{z}=$ vertical coordinate measured from the ground $(\mathrm{m})$

$C_{(x, y, z)}=$ mean concentration of diffusing substance at point $(\mathrm{x}, \mathrm{y}, \mathrm{z}),\left(\mathrm{kg} / \mathrm{m}^{3}\right)$

Unfortunately, the turbulent diffusivities $K_{y}$ and $K_{z}$ are unknown in most flows and in the atmospheric boundary layer $K_{z}$ is not constant but increases with height above the ground. In addition $K_{y}$ and $K_{z}$ increase with distance from the source (Beychok, 2005).

Defining the following Gaussian parameters

$\sigma_{y}=\sqrt{2 K_{y} \frac{x}{U}}$ and $\sigma_{z}=\sqrt{2} K_{z} \frac{x}{U}$

The final form of the Gaussian Plume equation for an elevated plume released at $z=H_{p}$

$\frac{n_{i}}{N}=\exp \frac{-\left(x_{i}-x_{m}\right)^{2}}{2 \sigma^{2} / \sigma \sqrt{2 \pi}}$

18

The Gaussian distribution equation, can be rearranged in a form that will be used to develop stack gas dispersion model

$n_{i}=\frac{N \exp -\left(x_{i}-x_{m}\right)^{2}}{2 \sigma^{2} / \sigma \sqrt{2} \pi}$

19

Neglecting the crosswind diffusion of the plume

$n_{r(x, z)}=\frac{N \exp -\left(Z_{i}-Z_{m}\right)^{2}}{2 \sigma_{z}^{2} / \sigma_{z} \sqrt{2 \pi}}$

20

Where $\mathrm{N}=$ total grams of emission

$Z_{r}=$ any receptor location in the $\mathrm{z}$-axis

$Z_{m}=$ location of mean emission density (plume centerline)

$\sigma_{z}=$ vertical dispersion coefficient of emission density (m)

$n_{r(x, z)}=$ integrated crosswind emission density $\left(\mathrm{g} / \mathrm{m}^{2}\right)$ 
$n_{r(x, z)}=\frac{N \exp -\left(Z_{r}-Z_{m}\right)^{2}}{2 \sigma_{z}^{2} / \sigma_{z} \sqrt{2 \pi}}+\frac{N \exp -\left(Z_{r}-Z_{m}\right)^{2}}{\frac{2 \sigma_{z}^{2}}{\sigma_{z} \sqrt{2 \pi}}}$

21

Let $N=\frac{Q}{U}$

$Z_{r}-Z_{m}=H_{r}-H_{m}$

$Z_{r}-Z_{m}=H_{r}-\left(-H_{e}\right)=H_{r}+H_{e}$

Where $H_{e}=$ height of plume centerline above the ground (m)

$H_{r}=$ height of receptor above the ground (m)

Substituting for $Z_{\mathrm{r}}$ and $Z_{\mathrm{m}}$ into the equation 3.21 above

$n_{r(x, z)}=\frac{Q / U \exp -\left(H_{r}-H_{e}\right)^{2}}{2 \sigma_{z}^{2} / \sigma_{z} \sqrt{2 \pi}}+\frac{Q / U \exp -\left(H_{r}-H_{e}\right)^{2}}{2 \sigma_{z}^{2} / \sigma_{z} \sqrt{2 \pi}}$

22

$n_{r(x, z)}=\frac{Q}{U \sigma_{z} \sqrt{2 \pi}}\left[\frac{\exp -\left(H_{r}-H_{e}\right)^{2}}{2 \sigma_{z}^{2}}+\frac{e q n-\left(H_{r}-H_{e}\right)^{2}}{2 \sigma_{z}^{2}}\right]$

23

Now including the crosswind Gaussian distribution in the y-dimension

The $y-\operatorname{dim}=n_{r(x, y, z)}=\frac{n_{r(x, z)} \exp -\left(y-y_{m}\right)^{2} / 2 \sigma_{y}^{2}}{\sigma_{z} \sqrt{2} \pi}$

$C=\frac{Q}{2 \pi U \sigma_{y} \sigma_{z}} \exp \frac{-y^{2}}{2 \sigma_{y}^{2}}\left[\exp \frac{-\left(Z_{r}-Z_{m}\right)^{2}}{2 \sigma_{z}^{2}}+\exp \frac{-\left(Z_{r}-Z_{m}\right)^{2}}{2 \sigma_{z}^{2}}\right]$

24

where $\mathrm{C}=$ concentration of emissions, $g / \mathrm{m}^{3}$, at any receptor located at:

$x$ meters downwind

$y$ meters crosswind from the centerline

$z_{r}$ meters above the ground

$\mathrm{Q}=$ source emission rate, $g / s$

$\mathrm{H}_{\mathrm{e}}=$ plume centerline height above ground, $\mathrm{m}$

$\mathrm{U}=$ horizontal wind velocity, $\mathrm{m} / \mathrm{s}$

$\sigma_{z}=$ vertical standard deviation of the emission distribution, $\mathrm{m}$

$\sigma_{y}=$ horizontal standard deviation of the emission, $\mathrm{m}$

The generalized Gaussian Dispersion Equation for a continous point-source plume is stated as:

$C=\frac{Q}{u \sigma_{z} \sigma_{y} 2 \pi} e^{-\frac{y^{2}}{2 \sigma_{y}^{2}}}\left[e^{-\left(z_{r}-H_{e}\right)^{2} / 2 \sigma_{z}^{2}}+e^{-\left(z_{r}-H_{e}\right)^{2} / 2 \sigma_{z}^{2}}\right]$

25

For ground level centreline concentration, receptor height $\mathrm{z}_{\mathrm{r}}=0$, therefore equation 25 reduces to

$C=\frac{Q}{u \sigma_{z} \sigma_{y} 2 \pi} e^{-\frac{y^{2}}{2 \sigma_{y}^{2}}} e^{-\frac{H^{2}}{2 \sigma_{z}^{2}}}$

26

This equation is valid only within the following constraints:

- Vertical and crosswind diffusion occur according to Gaussian distribution.

- Downwind diffusion is negligible compared to downwind transport.

- The emission rate, $\mathrm{Q}$, is continous and constant

- The horizontal wind velocity and the mean wind direction are constant

- There is no deposition, washout, chemical conversion or absorption of emission, and any emissions diffusing to the ground are reflected back into the plume

- There is no upper barrier to vertical diffusion and there is no crosswind diffusion barrier

- Emission reflected upward from the ground are distributed vertically as if released from an imaginary plume beneath the ground and are additive to the actual plume distribution

- The use of $\sigma_{z}$ and $\sigma_{y}$ as constants at a given downwind distance, and the assumption of an expanding conical plume, implicitly require homogenous turbulence throughout the $\mathrm{x}, \mathrm{y}$, and $\mathrm{z}$-dimensions of the plume. 
Pollutants are transported through the atmosphere by wind currents from their point of release to downwind receptors. They are dispersed and diluted so that an emission, toxic at its release point may be harmless at ground level downwind. The higher the release points above the surroundings and the more buoyant is the plume, the greater is the dilution. The major meteorological parameters controlling atmospheric dispersion are atmospheric stability and wind velocity (Gwendolyn et al., 1993).

\section{Components Of Natural Gas}

Table 1 shows the components of natural gas and their percentage compositions. $\mathrm{CO}_{2}$ from natural gas is also a source of pollutants from power generation by the cement plant.

Table 1: Components of Natural Gas and Their Percentage Composition

\begin{tabular}{ll}
\hline Component of gas & Percentage composition \\
\hline $\mathbf{C H}_{\mathbf{4}}$ & 47 \\
$\mathbf{C}_{\mathbf{2}} \mathbf{H}_{\mathbf{6}}$ & 18 \\
$\mathbf{C}_{\mathbf{3}} \mathbf{H}_{\mathbf{8}}$ & 20 \\
$\mathbf{C}_{\mathbf{4}} \mathbf{H}_{\mathbf{1 0}}$ & 5 \\
$\mathbf{C}_{\mathbf{5}} \mathbf{H}_{\mathbf{1 2}}$ & 9 \\
$\mathbf{N}_{\mathbf{2}} \mathbf{S}$ & 0.03 \\
$\mathbf{N O}$ & 0.022 \\
Others & 0.678 \\
\hline
\end{tabular}

(Source: Odigure, 1995)

\section{Combustion equations}

The equations below show the equations of complete combustion of the $\mathrm{CO}_{2}$ producing components in natural gas

$\mathrm{CH}_{4}+2 \mathrm{O}_{2} \rightarrow \mathrm{CO}_{2}+2 \mathrm{H}_{2} \mathrm{O}$

27

$\mathrm{C}_{2} \mathrm{H}_{6}+\frac{7}{2} \mathrm{O}_{2} \rightarrow 2 \mathrm{CO}_{2}+3 \mathrm{H}_{2} \mathrm{O}$

28

$\mathrm{C}_{3} \mathrm{H}_{8}+5 \mathrm{O}_{2} \rightarrow 3 \mathrm{CO}_{2}+4 \mathrm{H}_{2} \mathrm{O}$

29

$\mathrm{C}_{4} \mathrm{H}_{10}+\frac{13}{2} \mathrm{O}_{2} \rightarrow 4 \mathrm{CO}_{2}+5 \mathrm{H}_{2} \mathrm{O}$

30

$\mathrm{C}_{5} \mathrm{H}_{12}+8 \mathrm{O}_{2} \rightarrow 5 \mathrm{CO}_{2}+6 \mathrm{H}_{2} \mathrm{O}$

31

The total amount of $\mathrm{CO}_{2}$ released by burning $1 \mathrm{~g}$ of associated gas according to equations 27 to 31 and on the basis of percentage as shown in Table 1 was calculated to be $2.08 \mathrm{~g}$.

Therefore the equation for calculating the concentration of $\mathrm{CO}_{2}$ from the power plant is (Opotu, 2004)

$$
C_{\mathrm{CO}_{2}}=\frac{2.08 * \rho v}{u} * \exp \left(-0.5 *\left(\frac{y}{\delta_{y}}\right)^{2}\right) * \exp \left(-0.5 *\left(\frac{H}{\delta_{z}}\right)^{2}\right)
$$

Where $\rho=$ density of $\mathrm{CO}_{2}\left(\mathrm{~kg} / \mathrm{m}^{3}\right)$

$\mathrm{v}=$ volume of $\operatorname{gas}\left(\mathrm{m}^{3}\right)$

$\mathrm{u}=$ exist velocity of gas from the stack $(\mathrm{m} / \mathrm{s})$

$\mathrm{y}=$ distance along the $\mathrm{y}$-axis $(\mathrm{m})$

$\mathrm{H}=$ height of stack $(\mathrm{m})$

\section{Soil Analysis Result}

\section{Results And Discussion}

\section{Chemical characteristics of the soil of the project area}

The soils of the area are mainly classified as Ferruginous Tropical Soils, Hydro-Morphic Soils and the Ferralitic Soils. The summaries of the characteristics of the soil in the project area are as shown in the Tables 2 . 
Table 2: Chemical Characteristics of the Soil of the Project Area

\begin{tabular}{cccccccc}
\hline Parameters & Depth $(\mathbf{c m})$ & SS 1 & SS2 & SS3 & SS4 & SS5 & SS6 \\
\hline pH & $0-15$ & 4.14 & 4.12 & 3.53 & 4.25 & 4.88 & 3.54 \\
& $15-30$ & 4.12 & 4.33 & 3.74 & 4.22 & 4.86 & 3.64 \\
Organic & $0-15$ & 1.92 & 1.44 & 4.48 & 2.56 & 1.60 & 4.58 \\
Carbon & $15-30$ & 0.99 & 0.44 & 3.52 & 1.02 & 0.74 & 3.42 \\
Total & $0-15$ & 0.112 & 0.131 & 0.298 & 0.131 & 0.485 & 0.366 \\
Nitrogen & $15-30$ & 0.205 & 0.520 & 0.261 & 0.149 & 0.187 & 0.161 \\
Available & $0-15$ & 3.89 & 2.07 & 9.84 & 2.59 & 9.37 & 9.85 \\
phosphorus & $15-30$ & 3.63 & 0.26 & 1.81 & 1.04 & 1.55 & 1.41 \\
ECEC & $0-15$ & 2.35 & 2.07 & 7.21 & 2.64 & 1.43 & 7.31 \\
(meq/100g) & $15-30$ & 2.66 & 4.59 & 5.47 & 2.54 & 2.56 & 4.47 \\
Oil content & $0-15$ & 3.96 & 1.98 & 5.95 & 1.98 & 3.96 & 3.94 \\
(ppm) & $15-30$ & 0.00 & 3.96 & 1.98 & 3.96 & 3.96 & 2.96 \\
Clay (\%) & $0-15$ & 2.3 & 1.2 & 9.2 & 1.2 & 1.2 & 9.1 \\
Silts (\%) & $15-30$ & 3.2 & 1.2 & 19.2 & 5.2 & 1.2 & 15.2 \\
Sands (\%) & $0-15$ & 4.2 & 2.2 & 5.2 & 8.2 & 3.2 & 5.3 \\
& $15-30$ & 4.2 & 2.2 & 22.2 & 8.2 & 2.2 & 21.2 \\
\hline
\end{tabular}

SS - soil sampling location code.

\section{Heavy metals}

The heavy metals profile of the area indicates low levels of these metals in the soil except for iron and manganese content that are moderately high as a result of high acidity. The others have values that can easily be tolerated by most crops plants.

Table 3: Heavy metals content of composite soil samples

\begin{tabular}{cccccccc}
\hline $\begin{array}{c}\text { Heavy } \\
\text { metals }\end{array}$ & SS1 & SS2 & SS3 & SS4 & SS5 & SS6 & MEAN \\
\hline Iron & 35.24 & 7.83 & 254.48 & 109.62 & 11.75 & 109.62 & 83.78 \\
Manganese & 8.63 & 8.63 & 6.90 & 10.35 & 10.35 & 10.35 & 8.97 \\
Zinc & 0.33 & 1.47 & 1.64 & 1.64 & 0.98 & 1.64 & 1.21 \\
Copper & 1.22 & 1.22 & 1.83 & 1.53 & 2.44 & 1.53 & 1.65 \\
Chromium & 0.35 & 0.35 & 0.27 & 0.18 & 0.00 & 0.18 & 0.23 \\
Cadmium & 1.56 & 0.89 & 2.00 & 1.56 & 1.11 & 1.56 & 1.42 \\
Nickel & 1.22 & 0.79 & 0.94 & 0.87 & 0.43 & 0.87 & 0.85 \\
Lead & 0.13 & 0.04 & 0.19 & 0.04 & 0.03 & 0.04 & 0.086 \\
Vanadium & 0.23 & 0.17 & 0.23 & 0.45 & 0.4 & 0.45 & 0.30 \\
\hline SS - soil sample
\end{tabular}

SS - soil sample locations

The ECEC of the soil in the study area is generally low. The top soil has relatively lower values than the subsoil with a mean of $3.14 \mathrm{meq} / 100 \mathrm{~g}$ and $3.56 \mathrm{meq} / 100 \mathrm{~g}$ respectively. These values could be due to high acidity and availability of few/unstable charges at the exchange sites of the kaolinitic clay. This property makes the soil unsuitable for agriculture except with the application of compound NPK fertilizers and liming.

The available phosphorus in the soil of the project area is very limited. The values for the top soil range from $2.07 \mathrm{ppm}$ to $9.84 \mathrm{ppm}$ (mean $5.54 \mathrm{ppm}$ ) while values for subsoil range from $0.26 \mathrm{ppm}$ to $3.63 \mathrm{ppm}$ (mean $1.66 \mathrm{ppm}$ ). This could be due to high acidity and mobilization of $\mathrm{Al}^{3+}$ and $\mathrm{Zn}^{3+}$ ions to form complexes with available phosphorus thereby being unavailable to plants. These values are all below the $10-15 \mathrm{ppm}$ critical level required for most crops.

\section{Sediments}

The characteristics of a sediment samples from the surface water bodies are presented in the Table 4 . The sediments were all sandy in texture and dark grey in colour. The samples were acidic with $\mathrm{pH}$ values ranging from 5.4 to 6.5 and electrical conductivity of $2.12-3.67 \mathrm{meq} / 100 \mathrm{~g}$ with carbon contents ranging from 0.13 to $1.2 \%$.

Nitrogen and phosphorous were low $(0.08-0.30 \mathrm{ppm}$, and $0.28-4.45 \mathrm{ppm}$ respectively) and heavy metal contents were below permissible limits. 
Table 4: Chemical characteristics of sediments in project area

\begin{tabular}{|c|c|c|c|}
\hline Parameters & ST 1 & ST2 & ST3 \\
\hline $\mathbf{p H}$ & 5.4 & 6.3 & 6.3 \\
\hline C & 0.96 & 0.13 & 1.21 \\
\hline $\mathbf{N}$ & 0.09 & 0.011 & 0.01 \\
\hline $\mathbf{P}(\mathbf{p p m})$ & 4.24 & 0.28 & 4.35 \\
\hline $\mathrm{NO}_{4}(\mathrm{ppm})$ & 0.20 & 0.14 & 0.30 \\
\hline $\mathrm{NO}_{3}(\mathrm{ppm})$ & 0.08 & 0.24 & 0.09 \\
\hline $\mathrm{NO}_{2}(\mathrm{ppm})$ & 0.10 & 0.007 & 0.10 \\
\hline $\mathrm{SO}_{4}{ }^{2-}(\mathrm{ppm})$ & 0.11 & 0.11 & 0.14 \\
\hline $\mathrm{Na}(\mathrm{meq} / 100 \mathrm{~g})$ & 0.17 & 0.13 & 0.20 \\
\hline K (meq/100g) & 0.45 & 0.07 & 0.46 \\
\hline $\mathrm{Ca}(\mathrm{meq} / \mathbf{1 0 0 g})$ & 1.76 & 0.88 & 1.81 \\
\hline $\mathrm{Mg}(\mathrm{meq} / \mathbf{1 0 0 g})$ & 0.24 & 0.54 & 0.55 \\
\hline $\mathrm{Al}^{3+}(\mathrm{meq} / \mathbf{1 0 0 g})$ & 0.7 & 0.01 & 0.20 \\
\hline $\operatorname{ECEC~}(\mathrm{meq} / \mathbf{1 0 0 g})$ & 3.62 & 2.12 & 3.67 \\
\hline Clay (\%) & 4.0 & 0.0 & 5.0 \\
\hline Silt (\%) & 7.8 & 0.0 & 8.7 \\
\hline Sand $(\%)$ & 88.2 & 100 & 86.3 \\
\hline Mn (ppm) & 0.49 & 0.73 & 0.65 \\
\hline Zn (ppm) & 1.78 & 1.15 & 1.25 \\
\hline $\mathrm{Cu}(\mathrm{ppm})$ & 14.11 & 2.35 & 10.41 \\
\hline $\mathbf{P b}(\mathbf{p p m})$ & 0.03 & 0.06 & 0.03 \\
\hline $\mathrm{Hg}$ (ppm) & 0.067 & 0.051 & 0.04 \\
\hline THC (ppm) & 0.4 & 1.0 & 0.98 \\
\hline
\end{tabular}

ST - sediment type

The texture of the soils in the area is generally sandy except in the subsoil where the texture is sandy loam and clay. The sand content is very high and above $80 \%$ in most places sampled while the silt and clay contents are low. The contents of these smaller particles are more in the subsoil $(15-30 \mathrm{~cm})$ than in the top $(0-$ $15 \mathrm{~cm}$ ), indicating illuviation. The $\mathrm{pH}$ value of less than 5 indicates strong acidic conditions for both top and subsoils. However, the $\mathrm{pH}$ of the top soil is relatively lower than that of the subsoil probably as a result of leaching. Soil pH of between $5-7.5$ is associated with high fertility. The mean values of percentage total nitrogen in the soils of the location reveal moderately high values. The distribution pattern is such that the topsoil levels (mean $0.0231 \%$ ) are lower than that of the subsoil (mean $0.262 \%$ ). This could be due to the mobility of nitrogen as a result of nitrate leaching. The organic carbon is moderately high. Higher values were recorded in the top soil $(1.44-4.485)$ than in the subsoil $(0.48-3.525)$. These values are however more than the $1.0 \%$ critical level required for optimum yield in most arable crops.

The study shows that emissions from vehicular movement during material transportation, cement evacuation, limestone as well as gypsum transportation will be direct/indirect, and significant. Emissions from earth-moving and construction equipment and other vehicles plying the road are likely to increase the concentration of carbon monoxide, nitrogen oxide, lead, hydrocarbons and particulate matter along the project route. Exposure to carbon monoxide can interfere with the absorption of oxygen haemoglobin and an acute exposure to nitrogen oxide is a major cause of respiratory disease, while hydrocarbon concentrations can cause severe eye irritation, coughing and sneezing. Mitigating measures will be required to reduce the impact on the air quality.

Increased environmental temperatures will have an effect on the environment.

\section{Water Quality}

Physio-chemical characteristics of surface water

The summary of the physio-chemical characteristics of the Ogun River is indicated in the Table 5. Sampling was conducted along the existing water bodies and the water bodies' exhibiting similar characteristics - temperatures ranged from $28.7^{\circ} \mathrm{C}$ to $32.2^{\circ} \mathrm{C}$ and $\mathrm{pH}$ values ranged from 6.48 to 8.24 . 
Table 5: Physio-Chemical Parameters of Ogun River

\begin{tabular}{|c|c|c|c|c|c|c|}
\hline Parameter & WS 1 & WS 2 & WS 3 & FEPA & DPR & WHO \\
\hline $\operatorname{Temp}\left({ }^{\circ} \mathrm{C}\right)$ & 28.7 & 29.7 & 30.7 & 35.0 & 35.0 & 25.0 \\
\hline $\mathbf{p H}$ & 6.78 & 6.61 & 7.53 & $6.5-8.5$ & $6.5-8.5$ & $6.5-8.5$ \\
\hline DO (mg/l) & 6.0 & 5.5 & 6.0 & Nil & nil & $>5.0$ \\
\hline BOD (mg/l) & 1.5 & 2.0 & 2.4 & 10 & 10 & Nil \\
\hline COD (mg/l) & 6.9 & 10.4 & 8.0 & Nil & 40 & Nil \\
\hline Elect & 21.44 & 21.73 & 11.66 & Nil & nil & 4000 \\
\hline \multicolumn{7}{|l|}{$\begin{array}{l}\text { Conductivity } \\
\text { (us/cm) }\end{array}$} \\
\hline TDS (mg/l) & 10.21 & 10.6 & 5.80 & - & 200 & - \\
\hline $\begin{array}{c}\text { Turbidity } \\
\text { (mg/l) }\end{array}$ & 6.10 & 8.09 & 14.41 & 10 & 10 & 5.0 \\
\hline TSS (mg/l) & 16.9 & 21.4 & 29.4 & 30 & 30 & Nil \\
\hline $\mathrm{Cl}^{-}(\mathrm{mg} / \mathrm{l})$ & 16.0 & 19.0 & 39.0 & 600 & 600 & 250 \\
\hline $\mathrm{NO}_{3}(\mathrm{mg} / \mathrm{l})$ & 0.48 & 0.55 & 0.54 & Nil & Nil & 45 \\
\hline $\mathrm{NO}_{2}(\mathrm{mg} / \mathrm{l})$ & 1.8 & 1.5 & 2.1 & Nil & nil & 0.1 \\
\hline $\mathrm{NH}_{4-}(\mathrm{mg} / \mathrm{l})$ & 5.7 & 4.5 & 5.0 & Nil & nil & Nil \\
\hline $\mathrm{SO}_{4}{ }^{3-}(\mathrm{mg} / \mathrm{l})$ & 6.7 & 6.8 & 6.5 & nil & nil & 400 \\
\hline $\mathrm{PO}_{4}{ }^{3-}(\mathrm{mg} / \mathrm{l})$ & 2.01 & 2.46 & 4.35 & Nil & nil & 5.0 \\
\hline THC (mg/l) & 4.2 & 4.5 & 8.6 & 10 & Nil & 0.01 \\
\hline $\mathrm{K}(\mathrm{mg} / \mathrm{l})$ & 1.81 & 3.02 & 4.45 & - & - & - \\
\hline $\mathrm{Ca}(\mathrm{mg} / \mathrm{l})$ & 0.4 & 0.44 & 0.49 & - & - & 7.5 \\
\hline $\mathrm{Mg}(\mathrm{mg} / \mathrm{l})$ & 0.2 & 0.3 & 0.26 & - & - & 3.0 \\
\hline Hg (mg/l) & 0 & 0 & 0 & 0.1 & 0.1 & 0.1 \\
\hline Pb (mg/l) & 0 & 0 & 0 & 0.05 & 0.05 & 0.05 \\
\hline $\mathrm{Fe}(\mathrm{mg} / \mathrm{l})$ & 0.3 & 0.41 & 1.85 & 1.0 & 1.0 & 0.3 \\
\hline $\operatorname{Mn}(\mathrm{mg} / \mathrm{l})$ & 0.35 & 0.55 & 0.35 & Nil & Nil & 0.1 \\
\hline $\mathrm{Cu}(\mathrm{mg} / \mathrm{l})$ & NO & ND & ND & 1.5 & 1.5 & 1.0 \\
\hline $\mathrm{Cr}(\mathrm{mg} / \mathrm{l})$ & 0.9 & 1.8 & 3.0 & 1.03 & 1.03 & 0.05 \\
\hline $\mathrm{Zn}(\mathrm{mg} / \mathrm{l})$ & 0.02 & 0.68 & 0.44 & 1.0 & 1.0 & 5.0 \\
\hline Ni (mg/l) & 0 & 0 & 0 & Nil & Nil & Nil \\
\hline $\mathrm{V}(\mathrm{mg} / \mathrm{l})$ & 0 & 0 & 0 & Nil & nil & Nil \\
\hline
\end{tabular}

WS - water sample location (Source: WHO, 2010)

Physio-chemical characteristics of ground water

The summary of the physio-chemical characteristics of ground water in the projected area is indicated in the Table 6 .

Table 6: Summary of Physio-chemical Characteristics of Ground Water

\begin{tabular}{|c|c|c|c|}
\hline Parameters (units) & BH 1 & BH 2 & BH 3 \\
\hline Temperature $\left({ }^{\circ} \mathbf{C}\right)$ & 26.50 & 27.20 & 26.80 \\
\hline pH & 5.46 & 5.58 & 5.84 \\
\hline Conductivity $(\mu \mathrm{S} / \mathrm{cm})$ & 53.50 & 115.70 & 48.20 \\
\hline TDS (mg/l) & 27.25 & 56.35 & 24.60 \\
\hline Turbidity (NTU) & 1.46 & 2.98 & 9.51 \\
\hline DO (mg/l) & 3.36 & 3.57 & 3.84 \\
\hline $\mathrm{Na}(\mathrm{mg} / \mathrm{l})$ & 12.61 & 14.46 & 11.48 \\
\hline TSS (mg/l) & 2.24 & 3.62 & 6.56 \\
\hline Oil (mg/l) & ND & ND & ND \\
\hline TOC (mg/l) & 4.42 & 5.01 & 1.12 \\
\hline Bicarbonates (mg/l) & 11.61 & 22.14 & 11.51 \\
\hline Sulphates (mg/l) & $<1.0$ & $<1.0$ & $<1.0$ \\
\hline Nitrates (mg/l) & $<0.1$ & 0.21 & $<0.1$ \\
\hline Ammonium (mg/l) & 0.27 & 0.14 & 0.32 \\
\hline $\mathrm{Cr}$ (mg/l) & 0.101 & 0.021 & 0.024 \\
\hline $\mathrm{Fe}(\mathrm{mg} / \mathrm{l})$ & 2.11 & 1.30 & 0.24 \\
\hline $\mathrm{Ni}(\mathrm{mg} / \mathrm{l})$ & 0.02 & 0.03 & 0.06 \\
\hline $\mathrm{Pb}(\mathrm{mg} / \mathrm{l})$ & 0.012 & 0.032 & 0.24 \\
\hline
\end{tabular}




\begin{tabular}{cccc}
\hline $\mathbf{H g}(\mathbf{m g} / \mathbf{l})$ & $\mathrm{ND}$ & $\mathrm{ND}$ & $\mathrm{ND}$ \\
$\mathbf{M g}(\mathbf{m g} / \mathbf{l})$ & 0.63 & 1.41 & 0.43 \\
$\mathbf{M n}(\mathbf{m g} / \mathbf{l})$ & 0.010 & 0.02 & 0.102 \\
$\mathbf{C l}(\mathbf{m g} / \mathbf{l})$ & 13.3 & 12.6 & 12.9 \\
\hline
\end{tabular}

BH - ground water sample

Site preparation, excavated soils and compaction of soil create turbidity with high spatial extent, especially during the rainy season but these impacts will be of short duration. The overall negative impacts of these activities is however not significant. Effects of volatile and heavy metal compounds e.g. $\mathrm{Na}^{+}, \mathrm{K}^{+}$, on water quality will be increasing with time. Acidic oxides e.g. $\mathrm{CO}_{2}$, gradually increase the $\mathrm{pH}$ of the water. Pollution of ground water sources may arise as a result of inadequate disposal of refuse and other construction wastes. Runoff of sediments as a result of erosion and from dust and sand at construction site will lead to turbidity of surface water courses.

Noise Levels

Noise level in the projected area are presented in the Table 7.

Table 7: Noise Levels in the Study Area

\begin{tabular}{ll}
\hline Sample location & Noise level dBA \\
\hline $\mathbf{1}$ & 78.2 \\
$\mathbf{2}$ & 46.4 \\
$\mathbf{3}$ & 53.2 \\
$\mathbf{4}$ & 42.2 \\
$\mathbf{5}$ & 44.4 \\
$\mathbf{6}$ & 48.2 \\
FEPA limit & 55 \\
\hline
\end{tabular}

It is expected that noise levels will be highest at areas closest to the heavy equipment such as crushers and also due to movement of heavy duty vehicles.

\section{Inputs for The Model Equation}

The dispersion model was simulated using visual basic program. The input data for the program are presented below.

Table 8 gives the input variables for the model equations 18 and 24 .

Table 8: Input Data

\begin{tabular}{|c|c|c|c|c|c|c|c|c|c|c|c|c|}
\hline Month & $\begin{array}{l}\text { Input } \\
\text { data }\end{array}$ & $\mathbf{v}_{\mathrm{s}}(\mathbf{m} / \mathbf{s})$ & $\begin{array}{l}\mathbf{u} \\
(\mathbf{m} / \mathbf{s} \\
) \\
\end{array}$ & $\begin{array}{l}\mathbf{h} \\
(\mathbf{m})\end{array}$ & $\begin{array}{l}\mathbf{T}_{\mathrm{s}} \\
(\mathbf{K})\end{array}$ & $\mathbf{T}_{\mathrm{a}}(\mathbf{K})$ & $\begin{array}{l}\mathbf{d} \\
(\mathbf{m})\end{array}$ & $\begin{array}{l}\mathbf{m} \\
\left(\mathbf{m}^{3}\right)\end{array}$ & $d_{g}$ & $\underset{\left(\mathrm{kg} / \mathrm{m}^{2}\right)}{\rho}$ & $\begin{array}{l}V_{g} \\
\left(\mathbf{m}^{3}\right)\end{array}$ & $\begin{array}{l}\mathbf{Q} \\
(\mathrm{g} / \mathrm{sec})\end{array}$ \\
\hline \multirow[t]{2}{*}{ January } & $\begin{array}{c}\text { Power } \\
\text { Plant }\end{array}$ & 6.29 & 6 & 120 & $\begin{array}{c}413 . \\
15\end{array}$ & $\begin{array}{c}301.1 \\
5\end{array}$ & 4.5 & 2.08 & $\begin{array}{c}1.97 \\
7\end{array}$ & 1012 & 1000 & - \\
\hline & $\begin{array}{l}\text { Cement } \\
\text { Kiln }\end{array}$ & 8 & 6 & 90 & $\begin{array}{c}423 . \\
15\end{array}$ & $\begin{array}{c}301.1 \\
5\end{array}$ & 4.5 & - & - & - & - & 4434.3 \\
\hline \multirow[t]{2}{*}{ Febuary } & $\begin{array}{l}\text { Power } \\
\text { Plant }\end{array}$ & 6.29 & 8 & 120 & $\begin{array}{c}413 . \\
15\end{array}$ & $\begin{array}{c}303.1 \\
5\end{array}$ & 4.5 & 2.08 & $\begin{array}{c}1.97 \\
7\end{array}$ & 1012 & 1000 & - \\
\hline & $\begin{array}{l}\text { Cement } \\
\text { Kiln }\end{array}$ & 8 & 8 & 90 & $\begin{array}{c}423 . \\
14\end{array}$ & $\begin{array}{c}303.1 \\
5\end{array}$ & 4.5 & - & - & - & - & 4434.3 \\
\hline \multirow[t]{2}{*}{ March } & $\begin{array}{l}\text { Power } \\
\text { Plant }\end{array}$ & 6.29 & 6 & 120 & $\begin{array}{c}413 . \\
15\end{array}$ & $\begin{array}{c}303.1 \\
5\end{array}$ & 4.5 & 2.08 & $\begin{array}{c}1.97 \\
7\end{array}$ & 1012 & 1000 & - \\
\hline & $\begin{array}{l}\text { Cement } \\
\text { Kiln }\end{array}$ & 8 & 6 & 90 & $\begin{array}{c}423 . \\
15\end{array}$ & $\begin{array}{c}303.1 \\
5\end{array}$ & 4.5 & - & - & - & - & 4434.3 \\
\hline \multirow[t]{2}{*}{ April } & $\begin{array}{l}\text { Power } \\
\text { Plant }\end{array}$ & 6.29 & 8 & 120 & $\begin{array}{c}413 . \\
15\end{array}$ & $\begin{array}{c}301.1 \\
5\end{array}$ & 4.5 & 2.08 & $\begin{array}{c}1.97 \\
7\end{array}$ & 1012 & 1000 & - \\
\hline & $\begin{array}{l}\text { Cement } \\
\text { Kiln }\end{array}$ & 8 & 8 & 90 & $\begin{array}{c}423 . \\
15\end{array}$ & $\begin{array}{c}301.1 \\
5\end{array}$ & 4.5 & - & - & - & - & 4434.3 \\
\hline \multirow[t]{2}{*}{ May } & $\begin{array}{l}\text { Power } \\
\text { Plant }\end{array}$ & 6.29 & 6 & 120 & $\begin{array}{c}413 . \\
15\end{array}$ & $\begin{array}{c}302.1 \\
5\end{array}$ & 4.5 & 2.08 & $\begin{array}{c}1.97 \\
7\end{array}$ & 1012 & 1000 & - \\
\hline & $\begin{array}{l}\text { Cement } \\
\text { Kiln }\end{array}$ & 8 & 6 & 90 & $\begin{array}{c}423 . \\
15\end{array}$ & $\begin{array}{c}302.1 \\
5\end{array}$ & 4.5 & - & - & - & - & 4434.3 \\
\hline \multirow[t]{2}{*}{ June } & $\begin{array}{l}\text { Power } \\
\text { Plant }\end{array}$ & 6.29 & 5 & 120 & $\begin{array}{c}413 . \\
15\end{array}$ & $\begin{array}{c}300.1 \\
5\end{array}$ & 4.5 & 2.08 & $\begin{array}{c}1.97 \\
7\end{array}$ & 1012 & 1000 & - \\
\hline & $\begin{array}{l}\text { Cement } \\
\text { Kiln }\end{array}$ & 8 & 5 & 90 & $\begin{array}{c}423 . \\
15\end{array}$ & $\begin{array}{c}300.1 \\
5\end{array}$ & 4.5 & - & - & - & - & 4434.3 \\
\hline \multirow[t]{2}{*}{ July } & $\begin{array}{c}\text { Power } \\
\text { Plant }\end{array}$ & 6.29 & 8 & 120 & $\begin{array}{c}413 . \\
15\end{array}$ & $\begin{array}{c}299.1 \\
5\end{array}$ & 4.5 & 2.08 & $\begin{array}{c}1.97 \\
7\end{array}$ & 1012 & 1000 & - \\
\hline & $\begin{array}{c}\text { Cement } \\
\text { Kiln } \\
\end{array}$ & 8 & 8 & 90 & $\begin{array}{c}423 . \\
15 \\
\end{array}$ & $\begin{array}{c}299.1 \\
5 \\
\end{array}$ & 4.5 & - & - & - & - & 4434.3 \\
\hline
\end{tabular}


Environmental Impact Assessment Of A Proposed Cement Plant In Southwestern Nigeria

\begin{tabular}{|c|c|c|c|c|c|c|c|c|c|c|c|c|}
\hline \multirow[t]{2}{*}{ August } & $\begin{array}{c}\text { Power } \\
\text { Plant }\end{array}$ & 6.29 & 7 & 120 & $\begin{array}{c}413 . \\
15\end{array}$ & $\begin{array}{c}299.1 \\
5\end{array}$ & 4.5 & 2.08 & $\begin{array}{c}1.97 \\
7\end{array}$ & 1012 & 1000 & - \\
\hline & $\begin{array}{c}\text { Cement } \\
\text { Kiln }\end{array}$ & 8 & 7 & 90 & $\begin{array}{c}423 . \\
15\end{array}$ & $\begin{array}{c}299.1 \\
5\end{array}$ & 4.5 & - & - & - & - & 4434.3 \\
\hline \multirow[t]{2}{*}{$\begin{array}{l}\text { Septemb } \\
\text { er }\end{array}$} & $\begin{array}{c}\text { Power } \\
\text { Plant }\end{array}$ & 6.29 & 5 & 120 & $\begin{array}{c}413 . \\
15\end{array}$ & $\begin{array}{c}300.1 \\
5\end{array}$ & 4.5 & 2.08 & $\begin{array}{c}1.97 \\
7\end{array}$ & 1012 & 1000 & - \\
\hline & $\begin{array}{l}\text { Cement } \\
\text { Kiln }\end{array}$ & 8 & 5 & 90 & $\begin{array}{c}423 . \\
15\end{array}$ & $\begin{array}{c}300.1 \\
5\end{array}$ & 4.5 & - & - & - & - & 4434.3 \\
\hline \multirow[t]{2}{*}{ October } & $\begin{array}{c}\text { Power } \\
\text { Plant }\end{array}$ & 6.29 & 5 & 120 & $\begin{array}{c}413 . \\
15\end{array}$ & $\begin{array}{c}299.1 \\
5\end{array}$ & 4.5 & 2.08 & $\begin{array}{c}1.97 \\
7\end{array}$ & 1012 & 1000 & - \\
\hline & $\begin{array}{c}\text { Cement } \\
\text { Kiln }\end{array}$ & 8 & 5 & 90 & $\begin{array}{c}423 . \\
15\end{array}$ & $\begin{array}{c}299.1 \\
5\end{array}$ & 4.5 & - & - & - & - & 4434.3 \\
\hline \multirow[t]{2}{*}{$\begin{array}{l}\text { Novemb } \\
\text { er }\end{array}$} & $\begin{array}{l}\text { Power } \\
\text { Plant }\end{array}$ & 6.29 & 3 & 120 & $\begin{array}{c}413 . \\
15\end{array}$ & $\begin{array}{c}300.1 \\
5\end{array}$ & 4.5 & 2.08 & $\begin{array}{c}1.97 \\
7\end{array}$ & 1012 & 1000 & - \\
\hline & $\begin{array}{l}\text { Cement } \\
\text { Kiln }\end{array}$ & 8 & 3 & 90 & $\begin{array}{c}423 . \\
15\end{array}$ & $\begin{array}{c}300.1 \\
5\end{array}$ & 4.5 & - & - & - & - & 4434.3 \\
\hline \multirow[t]{2}{*}{$\begin{array}{l}\text { Decembe } \\
\mathbf{r}\end{array}$} & $\begin{array}{c}\text { Power } \\
\text { plant }\end{array}$ & 6.29 & 3 & 90 & $\begin{array}{c}413 . \\
15\end{array}$ & $\begin{array}{c}300.1 \\
5\end{array}$ & 4.5 & 2.08 & $\begin{array}{c}1.97 \\
7\end{array}$ & 1012 & 1000 & - \\
\hline & $\begin{array}{c}\text { Cement } \\
\text { kiln }\end{array}$ & 8 & 3 & 90 & $\begin{array}{c}423 . \\
15\end{array}$ & $\begin{array}{c}300.1 \\
5\end{array}$ & 4.5 & - & - & - & - & 4434.3 \\
\hline
\end{tabular}

\section{Simulated Results}

Table 9: Predicted $\mathrm{CO}_{2}$ concentration from the power plant

\begin{tabular}{|c|c|c|c|c|c|c|c|c|c|c|c|c|}
\hline \multirow{2}{*}{$\begin{array}{c}\text { Distanc } \\
\text { e (m) }\end{array}$} & \multicolumn{12}{|c|}{ CONCENTRATION $\left(\mu \mathrm{g} / \mathrm{m}^{3}\right)$} \\
\hline & Jan & Feb & $\begin{array}{c}\text { Marc } \\
h\end{array}$ & April & May & June & July & Aug & Sept & Oct & Nov & Dec \\
\hline $\mathbf{0}$ & 0 & 0 & 0 & 0 & 0 & 0 & 0 & 0 & 0 & 0 & 0 & 0 \\
\hline 100 & $\begin{array}{c}0.10 \\
620\end{array}$ & $\begin{array}{c}8.145 \\
0 \mathrm{e}-2\end{array}$ & $\begin{array}{c}0.106 \\
20\end{array}$ & $\begin{array}{c}8.145 \\
0 \mathrm{e}-2\end{array}$ & $\begin{array}{c}0.106 \\
20\end{array}$ & 0.1250 & $\begin{array}{c}8.1343 \\
\mathrm{e}-2\end{array}$ & $9.212 \mathrm{e}-2$ & 0.1250 & 0.1249 & 0.1897 & 0.1897 \\
\hline 200 & $\begin{array}{c}4.64 \\
58 \mathrm{e}- \\
2\end{array}$ & $\begin{array}{c}3.528 \\
0 \mathrm{e}-2\end{array}$ & $\begin{array}{l}4.645 \\
8 \mathrm{e}-2\end{array}$ & $\begin{array}{c}3.528 \\
0 \mathrm{e}-2\end{array}$ & $\begin{array}{l}4.645 \\
8 \mathrm{e}-2\end{array}$ & $\begin{array}{c}5.5146 \\
\mathrm{e}-2\end{array}$ & 0.0353 & $\begin{array}{c}4.0088 \mathrm{e}- \\
2\end{array}$ & $\begin{array}{c}5.5791 \mathrm{e}- \\
2\end{array}$ & $5.5126 \mathrm{e}-2$ & $\begin{array}{c}8.7277 \mathrm{e}- \\
2\end{array}$ & $\begin{array}{c}8.7277 \mathrm{e}- \\
2\end{array}$ \\
\hline 500 & $\begin{array}{c}1.60 \\
67 \mathrm{e}- \\
2\end{array}$ & $\begin{array}{l}1.207 \\
2 \mathrm{e}-2\end{array}$ & $\begin{array}{l}1.606 \\
7 \mathrm{e}-2\end{array}$ & $\begin{array}{l}1.207 \\
2 \mathrm{e}-2\end{array}$ & $\begin{array}{l}1.606 \\
7 \mathrm{e}-2\end{array}$ & $\begin{array}{c}1.9089 \\
\mathrm{e}-2\end{array}$ & $\begin{array}{c}1.2067 \\
\mathrm{e}-2\end{array}$ & $\begin{array}{c}1.3756 \mathrm{e}- \\
2\end{array}$ & $\begin{array}{c}1.9089 \mathrm{e}- \\
2\end{array}$ & $1.9085 \mathrm{e}-2$ & $\begin{array}{c}3.0995 \mathrm{e}- \\
2\end{array}$ & $\begin{array}{c}3.0995 \mathrm{e}- \\
2\end{array}$ \\
\hline 800 & $\begin{array}{c}9.43 \\
66 \mathrm{e}- \\
3\end{array}$ & $\begin{array}{c}7.101 \\
0 \mathrm{e}-3\end{array}$ & $\begin{array}{c}9.436 \\
6 \mathrm{e}-3\end{array}$ & $\begin{array}{c}7.101 \\
0 \mathrm{e}-3\end{array}$ & $\begin{array}{c}9.436 \\
6 \mathrm{e}-3\end{array}$ & $\begin{array}{c}1.1278 \\
\mathrm{e}-2\end{array}$ & $\begin{array}{c}7.1081 \\
\mathrm{e}-3\end{array}$ & $\begin{array}{c}8.1083 e- \\
3\end{array}$ & $\begin{array}{c}1.1278 \mathrm{e}- \\
2\end{array}$ & $1.1277 \mathrm{e}-2$ & $\begin{array}{c}1.8441 \mathrm{e}- \\
2\end{array}$ & $\begin{array}{c}1.8441 \mathrm{e}- \\
2\end{array}$ \\
\hline 1000 & $\begin{array}{c}7.38 \\
42 \mathrm{e}- \\
3\end{array}$ & $\begin{array}{l}5.560 \\
3 e-3\end{array}$ & $\begin{array}{l}7.384 \\
2 \mathrm{e}-3\end{array}$ & $\begin{array}{l}5.560 \\
3 e-3\end{array}$ & $\begin{array}{l}7.384 \\
2 \mathrm{e}-3\end{array}$ & $\begin{array}{c}8.8297 \\
\mathrm{e}-3\end{array}$ & $\begin{array}{c}5.5590 \\
\mathrm{e}-3\end{array}$ & $\begin{array}{c}6.3428 \mathrm{e}- \\
3\end{array}$ & $\begin{array}{c}8.8297 \mathrm{e}- \\
3\end{array}$ & $8.8287 \mathrm{e}-3$ & $\begin{array}{c}1.4473 \mathrm{e}- \\
2\end{array}$ & $\begin{array}{c}1.4473 \mathrm{e}- \\
2\end{array}$ \\
\hline 1500 & $\begin{array}{c}4.77 \\
24 \mathrm{e}- \\
3\end{array}$ & $\begin{array}{c}3.590 \\
6 \mathrm{e}-3\end{array}$ & $\begin{array}{c}4.772 \\
4 \mathrm{e}-3\end{array}$ & $\begin{array}{c}3.590 \\
6 \mathrm{e}-3\end{array}$ & $\begin{array}{c}4.772 \\
4 \mathrm{e}-3\end{array}$ & $\begin{array}{c}5.7109 \\
\mathrm{e}-3\end{array}$ & $\begin{array}{c}3.5810 \\
\mathrm{e}-3\end{array}$ & $\begin{array}{c}4.0975 \mathrm{e}- \\
3\end{array}$ & $\begin{array}{c}5.7109 \mathrm{e}- \\
3\end{array}$ & $5.7103 e-3$ & $\begin{array}{c}9.3931 \mathrm{e}- \\
3\end{array}$ & $\begin{array}{c}9.3931 \mathrm{e}- \\
3\end{array}$ \\
\hline 2000 & $\begin{array}{c}3.52 \\
73 e- \\
3\end{array}$ & $\begin{array}{c}2.652 \\
6 \mathrm{e}-3\end{array}$ & $\begin{array}{c}3.527 \\
3 e-3\end{array}$ & $\begin{array}{c}2.652 \\
6 \mathrm{e}-3\end{array}$ & $\begin{array}{c}3.527 \\
3 e-3\end{array}$ & $\begin{array}{c}4.2226 \\
\mathrm{e}-3\end{array}$ & $\begin{array}{c}2.6522 \\
e-3\end{array}$ & $\begin{array}{c}3.0277 \mathrm{e}- \\
3\end{array}$ & $\begin{array}{c}4.2226 \mathrm{e}- \\
3\end{array}$ & $4.2222 \mathrm{e}-3$ & $\begin{array}{c}6.9583 \mathrm{e}- \\
3\end{array}$ & $\begin{array}{c}6.9583 \mathrm{e}- \\
3\end{array}$ \\
\hline 3000 & $\begin{array}{c}2.32 \\
81 \mathrm{e}- \\
3\end{array}$ & $\begin{array}{c}1.741 \\
0 \mathrm{e}-3\end{array}$ & $\begin{array}{c}2.328 \\
1 \mathrm{e}-3\end{array}$ & $\begin{array}{c}1.741 \\
0 \mathrm{e}-3\end{array}$ & $\begin{array}{c}2.328 \\
1 \mathrm{e}-3\end{array}$ & $\begin{array}{c}2.7882 \\
\mathrm{e}-3\end{array}$ & $\begin{array}{c}1.7498 \\
\mathrm{e}-3\end{array}$ & $\begin{array}{c}1.9979 \mathrm{e}- \\
3\end{array}$ & $\begin{array}{c}2.7882 \mathrm{e}- \\
3\end{array}$ & $2.7881 \mathrm{e}-3$ & $4.604 \mathrm{e}-3$ & $4.604 \mathrm{e}-3$ \\
\hline 4000 & $\begin{array}{c}1.74 \\
71 \mathrm{e}- \\
3\end{array}$ & $\begin{array}{l}1.312 \\
9 \mathrm{e}-3\end{array}$ & $\begin{array}{c}1.747 \\
1 \mathrm{e}-3\end{array}$ & $\begin{array}{l}1.312 \\
9 \mathrm{e}-3\end{array}$ & $\begin{array}{c}1.747 \\
1 \mathrm{e}-3\end{array}$ & $\begin{array}{c}2.0929 \\
\mathrm{e}-3\end{array}$ & $\begin{array}{c}1.3127 \\
\mathrm{e}-3\end{array}$ & $\begin{array}{c}1.4991 \mathrm{e}- \\
3\end{array}$ & $\begin{array}{c}2.0929 \mathrm{e}- \\
3\end{array}$ & $2.6927 \mathrm{e}-3$ & $\begin{array}{c}3.4597 \mathrm{e}- \\
3\end{array}$ & $\begin{array}{c}3.4597 \mathrm{e}- \\
3\end{array}$ \\
\hline 5000 & $\begin{array}{c}1.40 \\
45 \mathrm{e}- \\
3\end{array}$ & $\begin{array}{l}1.055 \\
3 e-3\end{array}$ & $\begin{array}{l}1.404 \\
5 \mathrm{e}-3\end{array}$ & $\begin{array}{l}1.055 \\
3 e-3\end{array}$ & $\begin{array}{c}1.404 \\
5 \mathrm{e}-3\end{array}$ & $\begin{array}{c}1.6827 \\
\mathrm{e}-3\end{array}$ & $\begin{array}{c}1.0551 \\
\mathrm{e}-3\end{array}$ & $\begin{array}{c}1.2050 \mathrm{e}- \\
3\end{array}$ & $\begin{array}{c}1.6827 \mathrm{e}- \\
3\end{array}$ & $1.6826 \mathrm{e}-3$ & $\begin{array}{c}2.7837 \mathrm{e}- \\
3\end{array}$ & $\begin{array}{c}2.7837 \mathrm{e}- \\
3\end{array}$ \\
\hline
\end{tabular}

Table 10: Predicted Ground level $\mathrm{PM}_{10}$ concentration from the cement kiln

\begin{tabular}{|c|c|c|c|c|c|c|c|c|c|c|c|c|}
\hline \multirow{2}{*}{$\begin{array}{c}\text { Distanc } \\
\text { e (m) }\end{array}$} & \multicolumn{12}{|c|}{ CONCENTRATION $\left(\mu \mathrm{g} / \mathrm{m}^{3}\right)$} \\
\hline & Jan & Feb & Mar & Apr & May & June & Jul & Aug & Sept & Oct & Nov & $\overline{D e c}$ \\
\hline $\mathbf{0}$ & 0 & 0 & 0 & 0 & 0 & 0 & 0 & 0 & 0 & 0 & 0 & 0 \\
\hline 100 & $\begin{array}{c}0.7779 \\
9\end{array}$ & $\begin{array}{c}0.6040 \\
2\end{array}$ & $\begin{array}{c}0.7779 \\
9\end{array}$ & $\begin{array}{c}0.6040 \\
2\end{array}$ & $\begin{array}{c}0.7779 \\
9\end{array}$ & 0.9083 & $\begin{array}{c}0.6028 \\
1\end{array}$ & $\begin{array}{c}0.6789 \\
5\end{array}$ & 0.9083 & $\begin{array}{c}0.9075 \\
9\end{array}$ & $\begin{array}{c}1.3567 \\
8\end{array}$ & $\begin{array}{c}1.3567 \\
8\end{array}$ \\
\hline 200 & $\begin{array}{c}0.3346 \\
4\end{array}$ & $\begin{array}{c}0.2580 \\
5\end{array}$ & $\begin{array}{c}0.3346 \\
4\end{array}$ & $\begin{array}{c}0.2580 \\
5\end{array}$ & $\begin{array}{c}0.3346 \\
4\end{array}$ & $\begin{array}{c}0.3930 \\
6\end{array}$ & 0.2576 & $\begin{array}{c}0.2909 \\
7\end{array}$ & $\begin{array}{c}0.3930 \\
6\end{array}$ & 0.3928 & $\begin{array}{c}0.6043 \\
9\end{array}$ & $\begin{array}{c}0.6043 \\
9\end{array}$ \\
\hline 500 & $\begin{array}{c}0.1051 \\
5\end{array}$ & $\begin{array}{c}8.75 \mathrm{E}- \\
02\end{array}$ & $\begin{array}{c}0.1051 \\
5\end{array}$ & $\begin{array}{c}8.75 \mathrm{E}- \\
02\end{array}$ & $\begin{array}{c}0.1051 \\
5\end{array}$ & 0.1344 & $\begin{array}{c}8.74 \mathrm{E}- \\
02\end{array}$ & $\begin{array}{c}9.89 \mathrm{E}- \\
02\end{array}$ & $\begin{array}{c}0.1344 \\
1\end{array}$ & $\begin{array}{c}0.1343 \\
5\end{array}$ & $\begin{array}{c}0.2104 \\
2\end{array}$ & $\begin{array}{c}0.2104 \\
2\end{array}$ \\
\hline 800 & $\begin{array}{c}6.71 \mathrm{E}- \\
02\end{array}$ & $\begin{array}{c}5.14 \mathrm{E}- \\
02\end{array}$ & $\begin{array}{c}6.71 \mathrm{E}- \\
02\end{array}$ & $\begin{array}{c}5.14 \mathrm{E}- \\
02\end{array}$ & $\begin{array}{c}6.71 \mathrm{E}- \\
02\end{array}$ & $\begin{array}{c}\text { 7.92E- } \\
02\end{array}$ & $\begin{array}{c}5.14 \mathrm{E}- \\
02\end{array}$ & $\begin{array}{c}5.81 \mathrm{E}- \\
02\end{array}$ & $\begin{array}{c}\text { 7.92E- } \\
02\end{array}$ & $\begin{array}{c}7.91 \mathrm{E}- \\
02\end{array}$ & $\begin{array}{c}0.1245 \\
2\end{array}$ & $\begin{array}{c}0.1245 \\
2\end{array}$ \\
\hline 1000 & $\begin{array}{c}5.24 \mathrm{E}- \\
02\end{array}$ & $\begin{array}{c}4.02 \mathrm{E}- \\
02\end{array}$ & $\begin{array}{c}5.24 \mathrm{E}- \\
02\end{array}$ & $\begin{array}{c}4.02 \mathrm{E}- \\
02\end{array}$ & $\begin{array}{c}5.24 \mathrm{E}- \\
02\end{array}$ & $\begin{array}{c}6.19 \mathrm{E}- \\
02\end{array}$ & $\begin{array}{c}4.01 \mathrm{E}- \\
02\end{array}$ & $\begin{array}{c}0.0454 \\
5\end{array}$ & $\begin{array}{c}6.19 \mathrm{E}- \\
02\end{array}$ & $\begin{array}{c}0.0618 \\
7\end{array}$ & $\begin{array}{c}9.75 \mathrm{E}- \\
02\end{array}$ & $\begin{array}{c}9.75 \mathrm{E}- \\
02\end{array}$ \\
\hline 1500 & $\begin{array}{c}3.38 \mathrm{E}- \\
02\end{array}$ & $\begin{array}{c}2.59 \mathrm{E}- \\
02\end{array}$ & $\begin{array}{c}3.38 \mathrm{E}- \\
02\end{array}$ & $\begin{array}{c}2.59 \mathrm{E}- \\
02\end{array}$ & $\begin{array}{c}3.38 \mathrm{E}- \\
02\end{array}$ & $\begin{array}{c}4.00 \mathrm{E}- \\
02\end{array}$ & $\begin{array}{c}2.59 \mathrm{E}- \\
02\end{array}$ & $\begin{array}{c}2.93 \mathrm{E}- \\
02\end{array}$ & $\begin{array}{c}4.00 \mathrm{E}- \\
02\end{array}$ & $\begin{array}{c}0.0399 \\
5\end{array}$ & $\begin{array}{c}6.31 \mathrm{E}- \\
02\end{array}$ & $\begin{array}{c}6.31 \mathrm{E}- \\
02\end{array}$ \\
\hline 2000 & $\begin{array}{c}2.50 \mathrm{E}- \\
02\end{array}$ & $\begin{array}{c}1.91 \mathrm{E}- \\
02\end{array}$ & $\begin{array}{c}2.50 \mathrm{E}- \\
02\end{array}$ & $\begin{array}{c}1.91 \mathrm{E}- \\
02\end{array}$ & $\begin{array}{c}2.50 \mathrm{E}- \\
02\end{array}$ & $\begin{array}{c}2.95 \mathrm{E}- \\
02\end{array}$ & $\begin{array}{c}1.91 \mathrm{E}- \\
02\end{array}$ & $\begin{array}{c}2.17 \mathrm{E}- \\
02\end{array}$ & $\begin{array}{c}2.95 \mathrm{E}- \\
02\end{array}$ & $\begin{array}{c}2.95 \mathrm{E}- \\
02\end{array}$ & $\begin{array}{c}4.67 \mathrm{E}- \\
02\end{array}$ & $\begin{array}{c}4.67 \mathrm{E}- \\
02\end{array}$ \\
\hline
\end{tabular}


Environmental Impact Assessment Of A Proposed Cement Plant In Southwestern Nigeria

\begin{tabular}{|c|c|c|c|c|c|c|c|c|c|c|c|c|}
\hline 3000 & $\begin{array}{c}1.65 \mathrm{E}- \\
02\end{array}$ & $\begin{array}{c}1.26 \mathrm{E}- \\
02\end{array}$ & $\begin{array}{c}1.65 \mathrm{E}- \\
02\end{array}$ & $\begin{array}{c}1.26 \mathrm{E}- \\
02\end{array}$ & $\begin{array}{c}1.65 \mathrm{E}- \\
02\end{array}$ & $\begin{array}{c}1.95 \mathrm{E}- \\
02\end{array}$ & $\begin{array}{c}1.26 \mathrm{E}- \\
02\end{array}$ & $\begin{array}{c}1.43 \mathrm{E}- \\
02\end{array}$ & $\begin{array}{c}1.95 \mathrm{E}- \\
02\end{array}$ & $\begin{array}{c}1.95 \mathrm{E}- \\
02\end{array}$ & $\begin{array}{c}3.09 \mathrm{E}- \\
02\end{array}$ & $\begin{array}{c}3.09 \mathrm{E}- \\
02\end{array}$ \\
\hline 4000 & $\begin{array}{c}0.0123 \\
6\end{array}$ & $\begin{array}{c}9.46 \mathrm{E}- \\
03\end{array}$ & $\begin{array}{c}0.0123 \\
6\end{array}$ & $\begin{array}{c}9.46 \mathrm{E}- \\
03\end{array}$ & $\begin{array}{c}0.0123 \\
6\end{array}$ & $\begin{array}{c}1.46 \mathrm{E}- \\
02\end{array}$ & $\begin{array}{c}9.45 \mathrm{E}- \\
03\end{array}$ & $\begin{array}{c}1.07 \mathrm{E}- \\
02\end{array}$ & $\begin{array}{c}1.46 \mathrm{E}- \\
02\end{array}$ & $\begin{array}{c}1.46 \mathrm{E}- \\
02\end{array}$ & $\begin{array}{c}2.32 \mathrm{E}- \\
02\end{array}$ & $\begin{array}{c}2.32 \mathrm{E}- \\
02\end{array}$ \\
\hline 5000 & $\begin{array}{c}9.93 \mathrm{E}- \\
03\end{array}$ & $\begin{array}{c}\text { 7.61E- } \\
03\end{array}$ & $\begin{array}{c}9.93 \mathrm{E}- \\
03\end{array}$ & $\begin{array}{c}\text { 7.61E- } \\
03\end{array}$ & $\begin{array}{c}9.93 \mathrm{E}- \\
03\end{array}$ & $\begin{array}{c}1.17 \mathrm{E}- \\
02\end{array}$ & $\begin{array}{c}\text { 7.60E- } \\
03\end{array}$ & $\begin{array}{c}8.60 \mathrm{E}- \\
03\end{array}$ & $\begin{array}{c}1.17 \mathrm{E}- \\
02\end{array}$ & $\begin{array}{c}1.17 \mathrm{E}- \\
02\end{array}$ & $\begin{array}{c}1.86 \mathrm{E}- \\
02\end{array}$ & $\begin{array}{c}1.86 \mathrm{E}- \\
02\end{array}$ \\
\hline
\end{tabular}

The climatic information was based on the data collected from the study area during field work (wet season, October 2010) and analysis of long term historical data were collected from the Nigerian Meteorological Agency, Abuja, covering wet and dry seasons. The weather conditions are influenced by the circulation of two air masses: the cold, dry and dusty continental air that originates from the Sahara desert in the North and warm, humid tropical maritime wind which originates from the Atlantic Ocean in the South. The area experiences a short dry season (between November and March) and a long wet season. Prevailing wind conditions in the wet season is southwesterly and varied between $1.23 \mathrm{~m} / \mathrm{s}$ and $3.45 \mathrm{~m} / \mathrm{s}$. the relative humidity and temperature ranges between $57.65 \%$ in the dry season to $83.4 \%$ in the wet season and $22.3^{\circ} \mathrm{C}$ respectively from historical data. Relative humidity values range from 77 to $92 \%$ (historical data for wet season $=76.1-83.0 \%$ ) whereas temperature ranges were $24.6-27.4 \mathrm{C}$ (historical data for the wet season $=25.4-29.5^{\circ} \mathrm{C}$ ). Available literature and field data indicates that the relative humidity and temperature values during the dry season are higher than the wet season. The prevailing wind conditions during the dry season is Northeasterly and with lower speed.

The prevailing wind speed range between 2.52 to $3.55 \mathrm{~m} / \mathrm{s}$ in the months of June and July and from 1.96 to $3.04 \mathrm{~m} / \mathrm{s}$ for the months of December and January. The prevailing wind direction in the months of June/July is West and South Westerly. The proposed location of the quarry is North of the community from the atmospheric model of the dust dispersion, the concentration of dust at ground level will be lower than the FMEnv limits of $250 \mu \mathrm{m} / \mathrm{m}^{3}$. The prevailing direction is not towards the community. The other communities in the area which are located in the direction of the wind are more than 7 to $8 \mathrm{~km}$ away from the plant site.

The climate of the region has two clearly defined seasons, the long dry season, which starts at the end of October and ends in March and the rainy season which lasts between the months of April and September. During the season the wettest months are between June and September.

The highest values for relative humidity were obtained between the months of April and November in the years considered. The trend coincides with the values obtained for rainfall. However the relatively high values for the month of November is as a result of the high moisture content of the soil at this time. The higher the relative humidity, the greater the rate of settling of the dust from the atmosphere.

The area is generally warm with average daily temperatures of about $30^{\circ} \mathrm{C}$ and a mean daily minimum of $27.5^{\circ} \mathrm{C}$. The hottest times in the year are in the months of February and March, with day time temperatures reaching up to $35^{\circ} \mathrm{C}$. This is the period preceding the onset of the minor rains. The mean daily temperature during this time is above $35.0^{\circ} \mathrm{C}$. The months of July and August are relatively cool with mean temperatures of $28.5^{\circ} \mathrm{C}$.

Dusts will also be generated from point or diffuse sources which include sources such as exhaust stack, while the diffuse sources of emissions are those that are scattered along the production line. Nevertheless, cement dusts constitute, if not controlled, a nuisance within the plant and the surroundings, as it affects not only the health of the employees working in the plant also the neighbouring communities, especially those downward. Adequate mitigation measures such as Electrostatic Precipitators (ESP) and Fabric Filters will be put in place to ensure almost zero fugitive SPM emission and limit exhaust PM emissions to less than $200 \mu \mathrm{g} / \mathrm{s}$. The downwind particle concentrations have been measured at different distances from the stack on a closer layer to the ground surface. The point of maximum concentration is approximately $750 \mathrm{~m}$ downwind. For distances close to the source the concentration of pollutants is lower and from this point to $750 \mathrm{~m}$ from the source, the particle concentration rapidly increases. Then the pollutant concentration is at first at a high rate and there after decreases to a slow rate.

There will be permanent land takeover during the project life span. This land take will lead to the loss of ecological habitat with some negative impact on plant and animal population.

The project terrain at the project site is relatively flat and low lying. Soil erosion is anticipated due to exposure of topsoil from bush clearing and excavation. The surface area to be exposed is a small fraction of the total land area in the project area. Hence, the impact is not significant, indirect, cumulative and is reversible.

Loss of flora and fauna due to bush clearing and exposure of top soil is expected to have a significant impact on the ecology and biodiversity.The loss of vegetation canopy will have significant impact on the soil since the project is expected to be on dry land. 
During the operation phase there will be significant noise pollution from the machinery. The projected noise level in some parts of the plant is expected to be close to the limit level 8 hour noise exposure so adequate hearing protection must be provided. The background noise levels and ground vibrations at the site will increase as a result of the movement of heavy duty vehicles. However the anticipated noise levels and ground vibrations will not have devastating effects on the work force and immediate environment. Potential sources of vibration include blasting in quarries, pilling in construction, road traffic and heavy machinery. Vibration transmitted from the site activities to the neigbourhood may therefore cause anxiety as well as annoyance to the community.

\section{Conclusions}

The following conclusions were made as a result of the conduct of the Environmental Impact Assessment study and the Air Dispersion modelling analysis carried out for the proposed cement plant:

1. Negative impacts associated with the proposed cement production plant are primarily loss of vegetation, which will be irreversible and insignificant. Mitigating measures aimed at reducing and possiblly eliminating such impacts should be put in place.

2. Increase in the volume of traffic which may cause a problem to the community.

3. The emission rate for PM to be emitted from the proposed cement plant is in compliance with emission standards. It can be inferred that these emission standards will not be exceeded based on the superior air pollution control technology to be installed by the proposed cement plant.

4. The model predictions for the proposed cement plant revealed compliance with the National Ambient Air Quality Standards and guideline concentration for the average periods of $250 \mu \mathrm{g} / \mathrm{m}^{3}$ daily mean.

\section{Acknowledgements}

My sincere and profound gratitude goes to God Almighty, for empowering me with grace and wisdom and seeing to the completion of this research work.

\section{References}

[1]. Beychok, M. B. (2005). Fundamentals of Stack Gas Dispersion: Fourth Edition. Author Published.

[2]. Carroll, B. \& Turpin, T. (2009). Environmental Impact Assessment Handbook: Second Edition.Thomas Telford Ltd

[3]. Cement Association of Canada (2001). Retrieved from www.cement.ca.

[4]. Cement Sustainability Initiative (2002). World Business Council for Sustainability Development (WBCSD) retrieved from http://www.wbcsdcement.org/concrete_misc.asp.

[5]. Federal Environmental Protection Agency (FMEnv) Act No. 59 of 1990. Laws of the Federal Republic of Nigeria.

[6]. Gwendolyn, H., Louis, T. and Ben, B.S. (1993). Handbook of Environmental Technology: A Wiley Inter Science Publication

[7]. Hendriks, C. A., Worrell, E., de Jager, D., Blok, K., Riemer, P. (2004). Emission Reduction of Greenhouse Gases from the Cement Industry: Greenhouse Gas Control Technologies Conference Paper, 3 - 4

[8]. International Association for Impact Assessment (1999). Principles of Environmental Impact Assessment Best Practice, pp 157 190.

[9]. Kreshkov, A.P., (1996). Basic Analytical Chemistry: Ximya T.4: Moscow.

[10]. Marlowe, I., Mansfield, D., Hurford, N., Bird, A., \& Wood, S. (2002). Towards a sustainable cement industry, Substudy 10: Environment, Health \& Safety Performance Improvement. Retrieved on June 29, 2008 from http://www.wbcsd.ch/web/projects/cement/tf3/final_report10.pdf, pp $12-38$

[11]. Smidth, F.L. (2006). Cement Making Process. Obajana Cement Plc. Lokoja, Kogi State, Nigeria.

[12]. United States Environmental Protection Agency (2004). Inventory of U.S Greenhouse Gas Emissions and Sinks. U.S Environmental Protection Agency, Washington, D.C. 